\title{
Structure and Function of Retinal Ganglion Cells Innervating the Cat's Geniculate Wing: An in vitro Study
}

\author{
M. Pu, D. M. Berson, and T. Pan \\ Department of Neuroscience, Brown University, Providence, Rhode Island 02912
}

We have examined in vitro the morphology and visual response properties of retinal ganglion cells innervating a component of the cat's lateral geniculate nucleus known as the geniculate wing (or retinorecipient zone of the pulvinar). Ganglion cells were first labeled in situ by retrograde transport of fluorescent microspheres from the geniculate wing. Labeled cells were injected intracellularly with Lucifer yellow and biocytin in the isolated retina and visualized immunohistochemically. With one exception, stained cells appeared to belong to a single morphological class that corresponded closely to the $\epsilon$ cell of earlier descriptions (Leventhal et al., 1980; Rodieck and Watanabe, 1986). They had somas comparable in size to those of $\beta$ cells and large, sparse dendritic trees that ramified in the inner (ON) sublayer of the inner plexiform layer. Dendritic fields increased in size with eccentricity, but only within the central retina, and were among the largest so far reported for cat ganglion cells, exceeding those of $\alpha$ cells at most eccentricities. Dendritic profiles were typically elliptical with long axes pointing toward the area centralis. Axons were about as thick as those of $\beta$ cells and thicker than those of other varieties of non- $\alpha$, non- $\beta$ ganglion cells.

We recorded extracellularly from microsphere-labeled, wing-projecting ganglion cells in a superfused, flattened eyecup preparation. All such cells exhibited sustained responses to standing contrast and had very large, concentric receptive fields with $\mathrm{ON}$-centers and OFF-surrounds. Their response to gratings showed that they have relatively poor spatial resolution and a moderate amount of nonlinearity of spatial summation. These cells thus have many physiological response properties in common with ganglion cells previously termed "on-center tonic W-cells," "on-center sluggish sustained cells," and "Q-cells."

These findings indicate that ganglion cells innervating the cat's geniculate wing form a structurally and functionally homogeneous class. Their large dendritic and receptive fields and low-pass spatial frequency tuning suggest that fine spatial resolution is not required for the execution of their functional role(s).

[Key words: W-cell, retina, ganglion cells, $\epsilon$ cells, lateral geniculate nucleus, in vitro]

\footnotetext{
Received Sept. 20, 1993; revised Dec. 27, 1993; accepted Jan. 13, 1994

We are grateful for technical advice from Dennis Dacey on intracellular staining and radial sections and from Mike Paradiso on designing and calibrating the stimulus display. We thank James McIlwain for comments on a draft of the manuscript. This work was supported by NIH R01 EY06108 and a Sloan Foundation Fellowship to D.M.B.

Correspondence should be addressed to Dr. David Berson, Department of Neuroscience, Box G-M401, Brown University, Providence, RI 02912

Copyright (c) 1994 Society for Neuroscience $0270-6474 / 94 / 144338-21 \$ 05.00 / 0$
}

Since the pioneering work of Kuffler (1953), the cat has provided one of the principal models for exploring the function and structure of retinal ganglion cells. By the 1970s, it had become well established that in addition to the major dichotomy based on center type (ON or OFF), there were two functional classes within the ganglion-cell population, usually termed $\mathrm{X}$ - and $\mathrm{Y}$-cells (Enroth-Cugell and Robson, 1966; Fukada, 1971; Cleland and Levick, 1973; Stone, 1983). Further work showed that these physiological cell types, $X$ and $Y$, corresponded respectively to two well-defined morphological classes, termed $\beta$ and $\alpha$ cells by Boycott and Wässle (1974). The strong correlation between structure and function has permitted inferences for both classes about the geometries of retinal sampling arrays, synaptic associations in the inner plexiform layer, patterns of efferent projection to the brain, and responses to environmental or surgical manipulation of the visual system.

It is now known that the $\mathrm{X}(\beta)$ and $\mathrm{Y}(\alpha)$ cell types together account for only about half of the ganglion cells in the cat's retina (see Stone, 1983, for review). The remaining cells are poorly understood. Though they have been lumped by some under a single designation ("W-cells" physiologically, or " $\gamma$ cells" morphologically), they are an exceedingly heterogeneous population in both structure and function and may eventually prove to constitute a set of separate types, as distinct from one another as they are from $X$ - and $Y$-cells (e.g., Boycotl and Wässle, 1974; Cleland and Levick, 1974a,b; Stone and Fukuda, 1974a,b; Kirk et al., 1976; Stone and Clarke, 1980; Kolb et al., 1981; EnrothCugell et al., 1983; Famiglietti, 1987; Stanford, 1987; Dacey, 1989).

In the search for a more comprehensive typology for such cells, a useful point of attack is the fact that subsets of them can be distinguished on the basis of their central projections (e.g., Leventhal et al., 1980, 1985; Farmer and Rodieck, 1982; Rowe and Dreher, 1982; Stone, 1983; Stanford, 1987; Distler and Hoffmann, 1989). A case in point is the retinal input to the geniculate wing, which has been suggested to arise largely or exclusively from a single subtype of non- $\alpha$, non- $\beta$ cell (Leventhal et al., 1980). Known also as the retinorecipient zone of the pulvinar, the geniculate wing is a thin sheet of cells lying at the lateral margin of the pulvinar nucleus. It receives direct input from both eyes and projects to the visual cortex (Berman and Jones, 1977; Shatz, 1977; Guillery et al., 1980, Leventhal et al., 1980). Its contiguity with the medial interlaminar nucleus of the dorsal lateral geniculate body prompted Guillery et al. (1980) to argue for its inclusion within the geniculate complex. The first evidence to suggest that the wing was innervated by ganglion cells other than $\alpha$ and $\beta$ cells was the fine caliber of its retinal afferents, as revealed in anterograde degeneration experiments (Guillery and Oberdorfer, 1977; Guillery et al., 1980). Retro- 
grade tracing studies showed that most ganglion cells innervating the wing had somas of medium size (Kawamura et al., 1979; Lcventhal et al., 1980) and large, sparsely branching dendritic trees (Leventhal et al., 1980). Leventhal and coworkers pointed out the somadendritic morphology of these cells distinguished them not only from $\alpha$ and $\beta$ cells, but also from the $\gamma$ and $\delta$ cells of Boycott and Wässle (1974), and they proposed the term " $\epsilon$ " to designate this provisional new type.

Rodieck and Watanabe (1986) marked wing-projecting ganglion cells by retrograde transport and then stained them intracellularly in the living, isolated retina in vitro. Their observations, reported in abstract form, supported the suggestion of Leventhal et al. (1980) that $\epsilon$ cells provide most or all of the retinal input to the wing. They also found that $\epsilon$ cells had dendritic fields much larger than had been evident from retrograde filling alone and that their dendrites ramified selectively in the inner half of the inner plexiform layer, that is, in the ON sublayer (Famiglietti and Kolb, 1976; Nelson et al., 1978).

In the present study, we have extended this in vitro approach to reexamine the ganglion cells innervating the cat's geniculate wing. We provide a comprehensive description of their morphology, including new data on their dendritic architecture, the effects of eccentricity on somadendritic form, and the caliber of their axons. In addition, we offer an initial assessment of their visual response properties based on extracellular recordings in vitro.

Some of these data have appeared in abstract form (Pu et al., 1992).

\section{Materials and Methods}

Retrograde labeling. Ganglion cells projecting to the geniculate wing were labeled by retrograde transport of fluorescent latex microspheres ("beads"; Katz et al., 1984; Katz and Iarovici, 1990). All surgery was done under aseptic conditions. Cats were surgically anesthetized with Nembutal (35 mg/kg, i.p., supplemented as needed i.v.) and placed in a stereotaxic apparatus. Respiratory secretions were controlled with atropine $(0.04 \mathrm{mg} / \mathrm{kg}, \mathrm{i} . \mathrm{m}$.). The nictitating membranes were retracted with phenylephrine hydrochloride and pupils dilated by topical application of atropine sulfate. Contact lenses of zero power were placed on the eyes.

Injections of the retrograde tracer were made through a micropipette (tip diameter, 20-50 $\mu \mathrm{m}$ ) using an electronically controlled solenoid device to deliver pulses of pneumatic pressure. To guide the placement of deposits, we initially filled the injection pipette with saline and made extracellular multiunit recordings with it to locate the dorsal border of geniculate layer $\mathrm{A}$ and the medial border of the medial interlaminar nucleus. The pipette's retinotopic position within the geniculate complex was estimated by reference to the maps of Sanderson (1971) and Lee et al. (1984). The pipette was then purged of saline, flushed with distilled water, and loaded with an equal-parts mixture of undiluted "red" and "green" fluorescent beads (Lumafluor, New City, NY; Molecular Probes, Eugene, OR). We injected the beads in a series of vertical penetrations $200-300 \mu \mathrm{m}$ apart lying in a single coronal plane to form a sheet-like deposit designed to intersect the wing while sparing all other retinorecipient nuclei. The sheet, which lay at least $1 \mathrm{~mm}$ anterior to the recording penetrations, was $2 \mathrm{~mm}$ wide and was centered mediolaterally on the estimated position of the medial border of the medial interlaminar nucleus. In individual penetrations, the injection pipette was driven down to a point $0.5 \mathrm{~mm}$ above the estimated depth of the dorsal border of layer $\mathrm{A}$, and small deposits (approximately $50 \mathrm{nl}$ ) were made $0.1 \mathrm{~mm}$ apart as the pipette was withdrawn. In some cases, a second sheet of deposits was made $1 \mathrm{~mm}$ anterior to the first. In three cases used for physiological studies, deposits were made bilaterally.

To determine the locations of bead deposits, brains were fixed by immersion or vascular perfusion with $10 \%$ formalin after removal of the eyes for the in vitro work (see below). Frozen sections through the injection sites were mounted and dried on glass slides and, without dehydration or defatting, examined with epifluorescence illumination.
The geniculate wing was invariably involved in the deposit and was the only retinorecipient structure involved in every case but one. In the exceptional case, which was used for morphological work only, beads marginally involved geniculate layer A. This collateral involvement can be discounted because the bead-labeled ganglion cells stained by intracellular injection in this animal's retinas were indistinguishable from those stained in the other retinas and were clearly not $\alpha$ or $\beta$ cells (which innervate the A-layers).

Intracellular staining in vitro. Methods used for staining ganglion cells in vitro have been described in detail elsewhere ( $\mathrm{Pu}$ and Berson, 1992). In brief, eyes were removed under deep barbiturate anesthesia and the animal killed with an overdose of Nembutal. The globe was hemisected just behind the limbus, the lens and vitreous removed, and the retina gently dissected free from the eyecup in oxygenated Ames medium (Sigma, St. Louis, MO). Several radial relieving cuts were made and the retinas were mounted on filter paper vitreal side up. The retina was placed in a chamber on a fixed-stage epifluorescence microscope (Olympus, Lake Success, NY) and superfused at a flow rate of about 4 $\mathrm{ml} / \mathrm{min}$ with oxygenated Ames medium at room temperature. Micropipettes containing $4 \%$ Lucifer yellow $\mathrm{CH}$ and $4 \%$ biocytin (Sigma, St. Louis, MO) in Tris buffer were positioned under a $40 \times$ water-immersion lens (Nikon, Garden City, NY) using a mechanical microdrive. Using epifluorescence filters appropriate for Lucifer yellow and green microspheres, the fluorescent pipette tip was advanced under visual guidance toward a bead-labeled ganglion cell. The cell was penetrated with brief pulses of oscillation (capacitance overcompensation) or high voltage from an intracellular amplifier (Neuro Data, New York, NY) connected to the electrode. Lucifer yellow and biocytin were then injected into the cell for several minutes with biphasic current pulses (up to $4 \mathrm{nA}$ negative and $0.5 \mathrm{nA}$ positive). In the rare instances in which there was any doubt that the cell being filled was the one we had aimed for, we confirmed the presence of retrograde labeling with red beads by viewing the stained cell with rhodamine filters. Up to 60 cells were injected in each retina over periods lasting up to $8 \mathrm{hr}$. Retinas were then fixed for $3 \mathrm{hr}$ in $4 \%$ paraformaldehyde in $0.1 \mathrm{~m}$ phosphate buffer $(\mathrm{pH} 7.4)$ and processed immunohistochemically for the intracellular dye as previously described (Pu and Berson, 1992). Stained cells were analyzed at the light microscope in cleared and coverslipped retinal whole-mounts. Measurements were made with a calibrated eyepiece graticule, those on soma or axonal diameter being made at a total magnification of $400-600 \times$. One stained neuron was examined in thionin-stained radial retinal sections of $5 \mu \mathrm{m}$ thickness after embedding in plastic.

Extracellular recording in vitro. Extracellular recordings were made from a flattened eyecup preparation that differed only slightly from the isolated retina used for the anatomical experiments. After removal of the lens and vitreous, several radial relieving cuts were made through all the layers of the globe and the eyecup was mounted as flat as possible, scleral side down, on a piece of filter paper. In the superfusion chamber, the free edges of the eyecup were held down by a plastic retaining ring. The dissection and recordings were done under dim red illumination and the intensity and duration of epifluorescence illumination were reduced as much as possible when locating and aiming for labeled ganglion cells. In order to compare the properties of wing-projecting cells with those of $\mathrm{X}$ - and $\mathrm{Y}$-cells in this preparation, we recorded from medium and large ganglion cells in superfused eyecups from several normal cats. In these cases, ganglion cells were visualized by periodic addition to the recording chamber of the vital dye acridine orange (a few drops of a $0.03 \%$ solution).

Recordings were made with micropipettes essentially identical to those used in the anatomical experiments, although we often had more success obtaining good recordings using electrodes at the low end of the impedance range. Signals were amplified, fed to an audio monitor, and stored on a digital tape recorder. Brief pulses of amplifier oscillation were often helpful in augmenting the amplitude of extracellular spikes. We frequently obtained recordings from ganglion-cell axons, even when the electrode tip appeared to be in close apposition to a ganglion-cell soma. These, which we have excluded from our sample, were recognizable from their waveform (Fukuda and Stonc, 1974) or becausc the receptive field was obviously displaced from the electrode tip.

Visual stimuli were presented by epi-illumination through the microscope's optics. Visual patterns generated on the screen of an overhead projector or on a computer monitor (see below) were imaged with a large Fresnel lens on the film plane of the microscope's camera port. This ensured that when the tip of the electrode was in focus in the eyepieces, the visual stimulus would also be sharply focused on the 

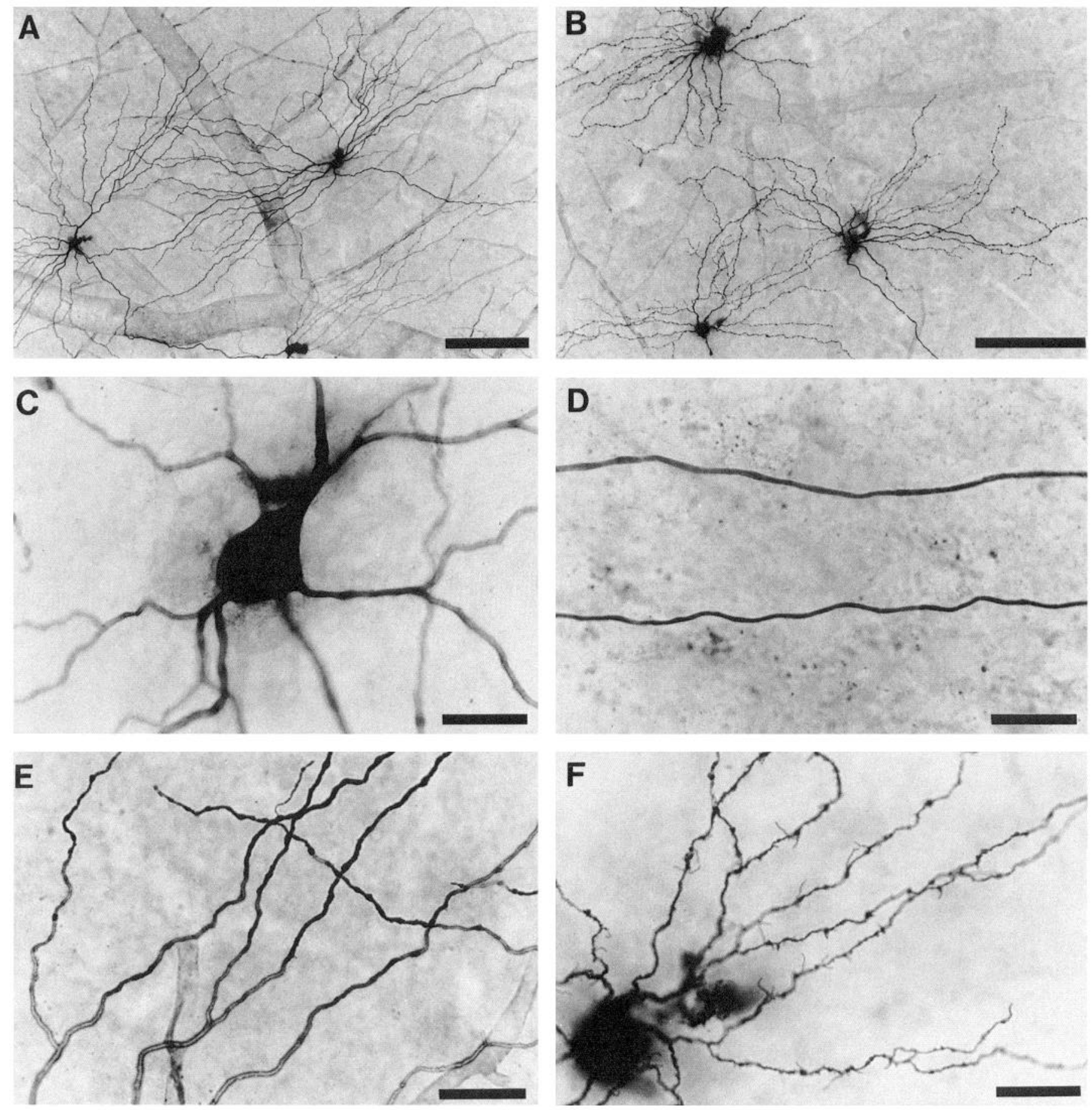

Figure 1. Photomicrographs illustrating the morphology of $\epsilon$ cells identified by retrograde transport from the geniculate wing and stained by intracellular injection in vitro. $A$, Several $\epsilon$ cells from the peripheral temporal retina labeled by retrograde transport from the ipsilateral wing. Eccentricity, $7 \mathrm{~mm}$. A drawing of the cell at left appears in Figure 5. B. Several $\epsilon$ cells from the pericentral temporal retina; same retina as in $A$. Eccentricity, $3 \mathrm{~mm}$. $C$, Higher-power view of the soma and proximal dendrites of an $\epsilon$ cell of the temporal retina. Same retina as in $A$. Eccentricity, $4 \mathrm{~mm}$. D. Axons of an $\epsilon$ cell (lower) and a $\beta$ cell (upper); note that the $\epsilon$-cell axon is nearly as thick as that of the $\beta$ cell. The parent cells lay near each other at an eccentricity of $8 \mathrm{~mm}$; they were labeled by retrograde transport from the contralateral medial interlaminar nucleus and then stained intracellularly. The illustrated axonal segments lay roughly $500 \mu \mathrm{m}$ from the somas. $E$. Typical dendritic morphology of $\epsilon$ cells. This is a higherpower view of the region of overlap between the two $\epsilon$ cells appearing in $A$. Note that at the points of overlap the processes of the two cells lie in the same focal plane. $F$, High-power view of dendritic morphology of an $\epsilon$ cell with atypically spiny dendrites. This cell lies in the temporal retina (same retina as in $A$ ) at an eccentricity of $1.6 \mathrm{~mm}$. A drawing of this cell appears at the bottom left of Figure 2. Scale bars: $A$ and $B, 200 \mu \mathrm{m} ; C$ $F, 25 \mu \mathrm{m}$.

retina when the camera's light path was opened. The dimensions of the visual stimulus on the retina could be changed by gingerly switching microscope objective lenses. To minimize vibrations during the exchange, we modified the objective nosepiece to suppress the normal click-stops. Linear stimulus dimensions were reduced by a factor of 100 from the screen to the retina when using the $4 \times$ objective and by a factor of 250 using the $10 \times$ objective. For convenience, stimulus dimensions on the retina will be given in degrees of visual angle using the 


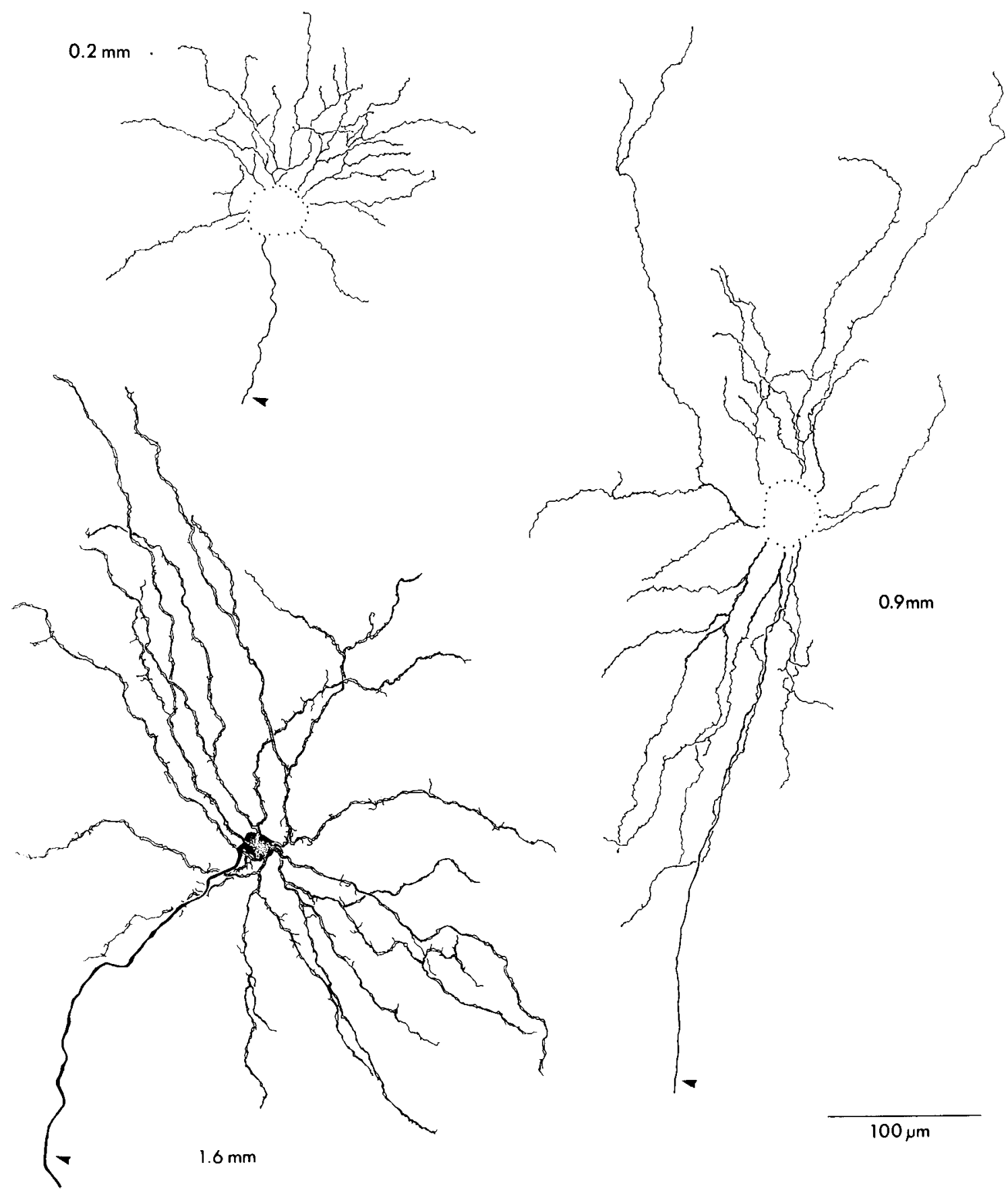

Figure 2. Camera lucida drawings of three $\epsilon$ cells of the central retina stained by intracellular injection in vitro. Eccentricities are noted beside each cell. Two of these cells (top and right) were labeled by retrograde transport from the contralateral geniculate wing and lay in the nasal retina. The somas of these two cells were obscured by artifacts, as indicated by the dotted outlines. The other cell (lower left) was labeled from the ipsilateral geniculate wing and lay in the temporal retina. This cell had atypically spiny dendrites; a photomicrograph of it appears in Figure $1 F$. Arrowheads indicate axons.

assumption that $1 \mathrm{~mm}$ on the retina is equivalent to $4.4^{\circ}$ (Bishop et al., 1962). The spectral composition of the stimulus was affected by its passing through the dichroic filter of the fluorescence attachments. This was nearly always the filter intended for visualizing Lucifer yellow (Olympus BH2-DMBG, O-515), which sharply attenuated wavelengths below $515 \mathrm{~nm}$ and caused white stimuli on the display to take on a desaturated yellow appearance after passing through the optics. Under these conditions, the luminance of the stimulus displays was reduced at the retina by a factor of 260 when using the $4 \times$ objective and by a factor of 41 using the $10 \times$. In rare instances, we used a rhodamine filter set (BH2-DMBG, O-590) that had a short-wavelength cutoff of $590 \mathrm{~nm}$ and yielded a reddish stimulus at the retina. Background light levels at the retina in the absence of stimulation were roughly $0.01 \mathrm{~cd} / \mathrm{m}^{2}$.
In early experiments, receptive-field properties were tested manually using stimuli produced on the screen of an overhead projector $(3 \mathrm{M}$, Austin, IX, model 905). 'The screen of the projector measured $12 \times$ $15 \mathrm{~cm}$, corresponding to $5.3^{\circ} \times 6.6^{\circ}$ on the retina using the $4 \times$ objective and $2.1^{\circ} \times 2.6^{\circ}$ for the $10 \times$ lens. Screen luminance was continuously adjustable by a transformer from 0 to $>20,000 \mathrm{~cd} / \mathrm{m}^{2}$ and was typically set to about $1000 \mathrm{~cd} / \mathrm{m}^{2}$ during receptive-field analysis. Black stimuli were generated by moving black paper cutouts on wands over the surface of the screen; white ones, by cutting apertures of various sizes into opaque masks covering the screen.

In later experiments, we generated stimuli on a computer monitor (NEC, Wood Dale, IL, Multisync 2A) driven by a programmable graphics card (SGT + , Number Nine Computer Corp., Lexington, MA) in an 


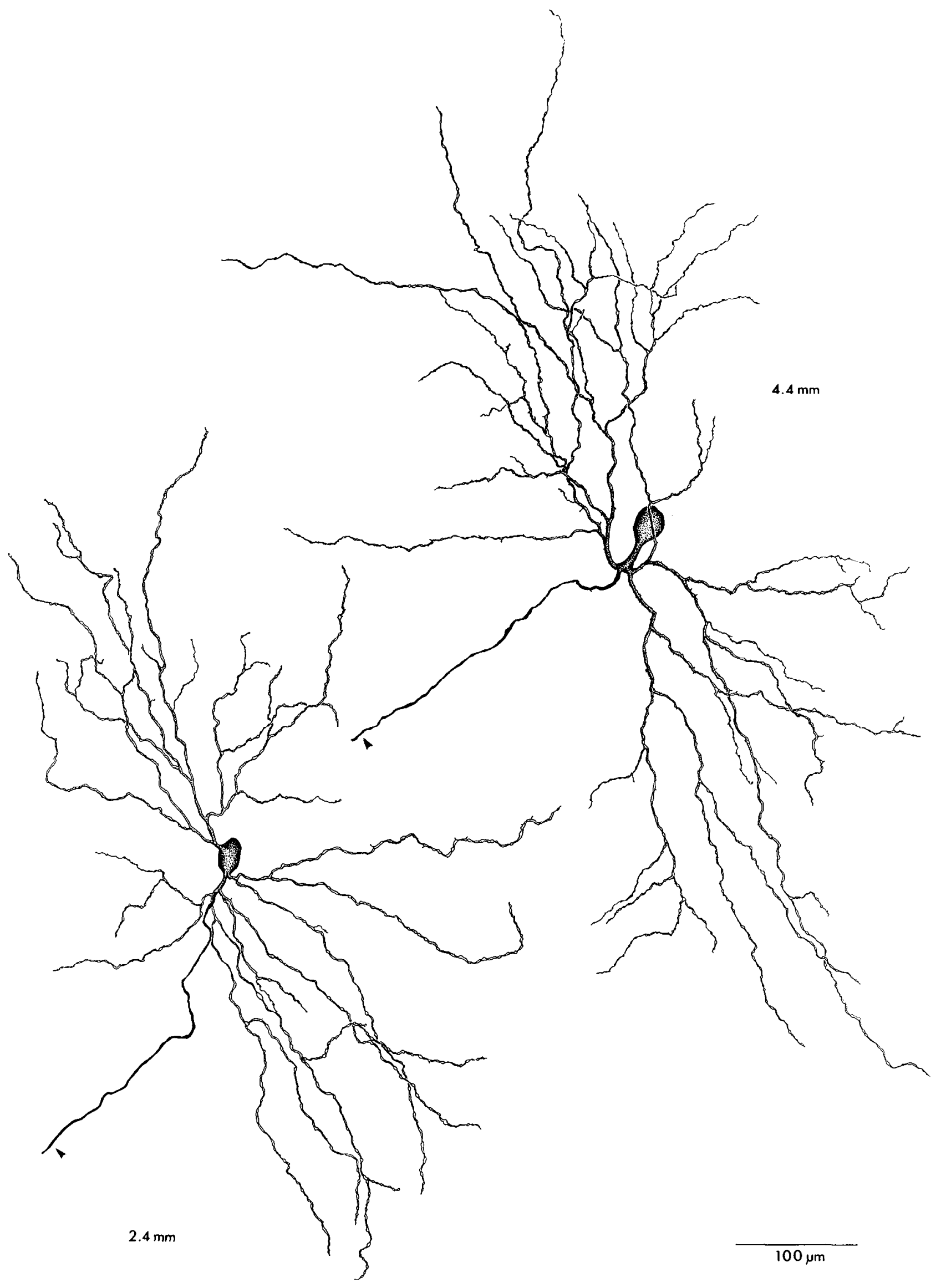

Figure 3. Camera lucida drawings of two wing-projecting $\epsilon$ cells of the pericentral retina. Cell at right lay in nasal retina and was labeled by retrograde transport from the contralateral wing. Cell at left lay in temporal retina and was labeled from the ipsilateral wing. Conventions are as for Figure 2. Note the pronounced elongation of the dendritic ficlds. 


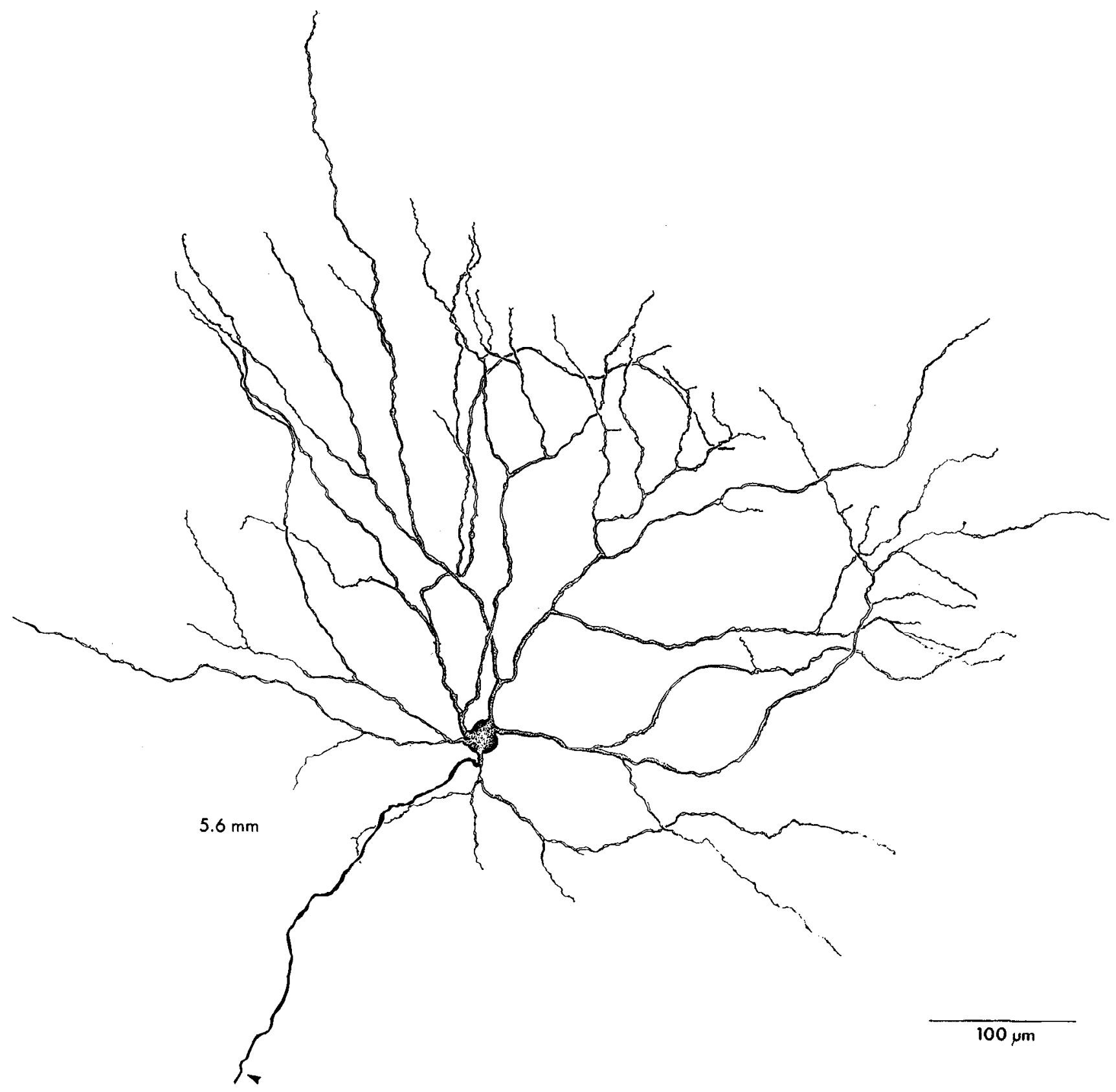

Figure 4. Camera lucida drawing of an $\epsilon$ cell from the peripheral temporal retina stained intracellularly after retrograde labeling from the ipsilateral wing. This cell was somewhat atypical in having a highly eccentric placement of its soma and somewhat more overlap of processes in the periphery of the dendritic field. Conventions are as for Figure 2.

IBM AT computer. The monitor measured $18 \times 24 \mathrm{~cm}$, translating to $7.9^{\circ} \times 10.6^{\circ}$ on the retina when using the $4 \times$ objective and $3.2^{\circ} \times 4.2^{\circ}$ when using the $10 \times$ lens. Screen luminance could be varied from 2 to $276 \mathrm{~cd} / \mathrm{m}^{2}$ with 8 -bit resolution. The screen had a resolution of $640 \times$ 480 pixels and a refresh rate of $60 \mathrm{~Hz}$. We programmed the graphics card to generate a wide variety of stimulus patterns, including light or dark stationary, flashing, or moving spots and sinusoidally modulated vertical gratings, either drifting or counterphasing. Screen luminance was calibrated with a photometer (Minolta CS-100, Ramsey, NJ) and software adjusted to correct for nonlinearities in the display. Synch pulses marking the timing of stimulus events were gencrated by the computer and stored on tape along with the spike train for subsequent off-line analysis. Receptive fields were plotted manually on acetate sheets affixed to the stimulus screen. For quantitative analysis of responses, peristimulus-time histograms were generated on a computer from the tape recordings using a hardware/software interface (Modular Instru- ments, Malvern, PA). For studies of responses to sinusoidal contrast gratings, we applied conventional Fourier analysis techniques (e.g., Hochstein and Shapley, 1976) to poststimulus-time histograms to determine the amplitudes of response components at the frequency of stimulation and at the second harmonic; the histograms were based on unit responses to at least 12 stimulus cycles. For figures displaying cell response as a function of the spatial position of counterphasing (contrastreversing) sinusoidal gratings (see Figs. 16, 17), values of spatial phase have been normalized so that a phase of zero corresponds to the position producing the maximum response at the fundamental stimulus frequency.

The topographic location of each recorded cell was determined by noting the microscope-stage coordinates of that cell, the optic disk, and the area centralis. In some cases, we stained the recorded cells by intracellular dye injection. Identification of some of these cells in the whole-mounts was impeded by inadvertent staining of other cells from 


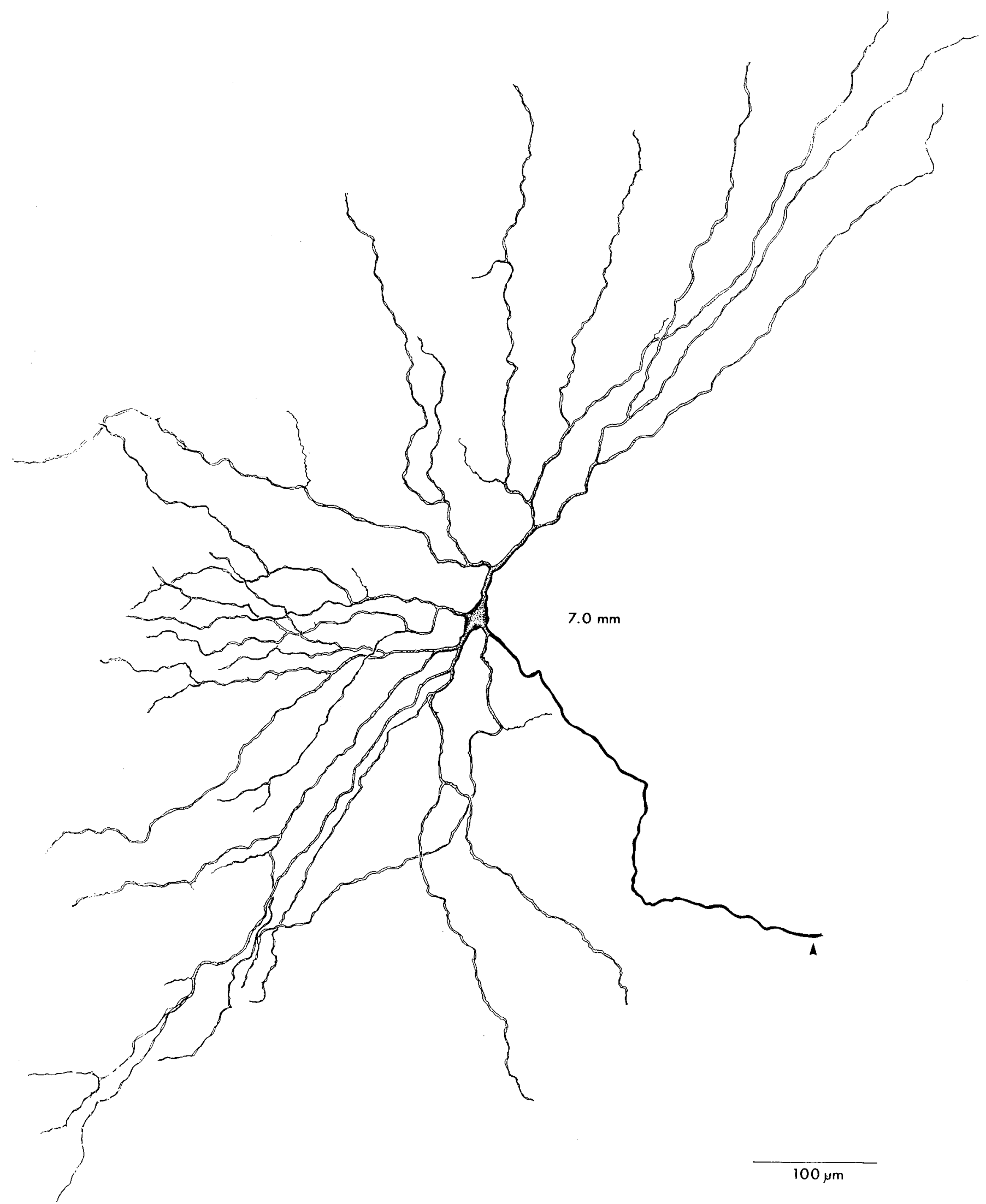

Figure 5. Camera lucida drawing of an $\epsilon$ cell located in the far periphery of the temporal retina with identified projection to the ipsilateral geniculate wing. Photomicrographs of this cell appear at the left of Figure $1 A$ and in Figure $1 E$. Conventions are as for Figure 2. 

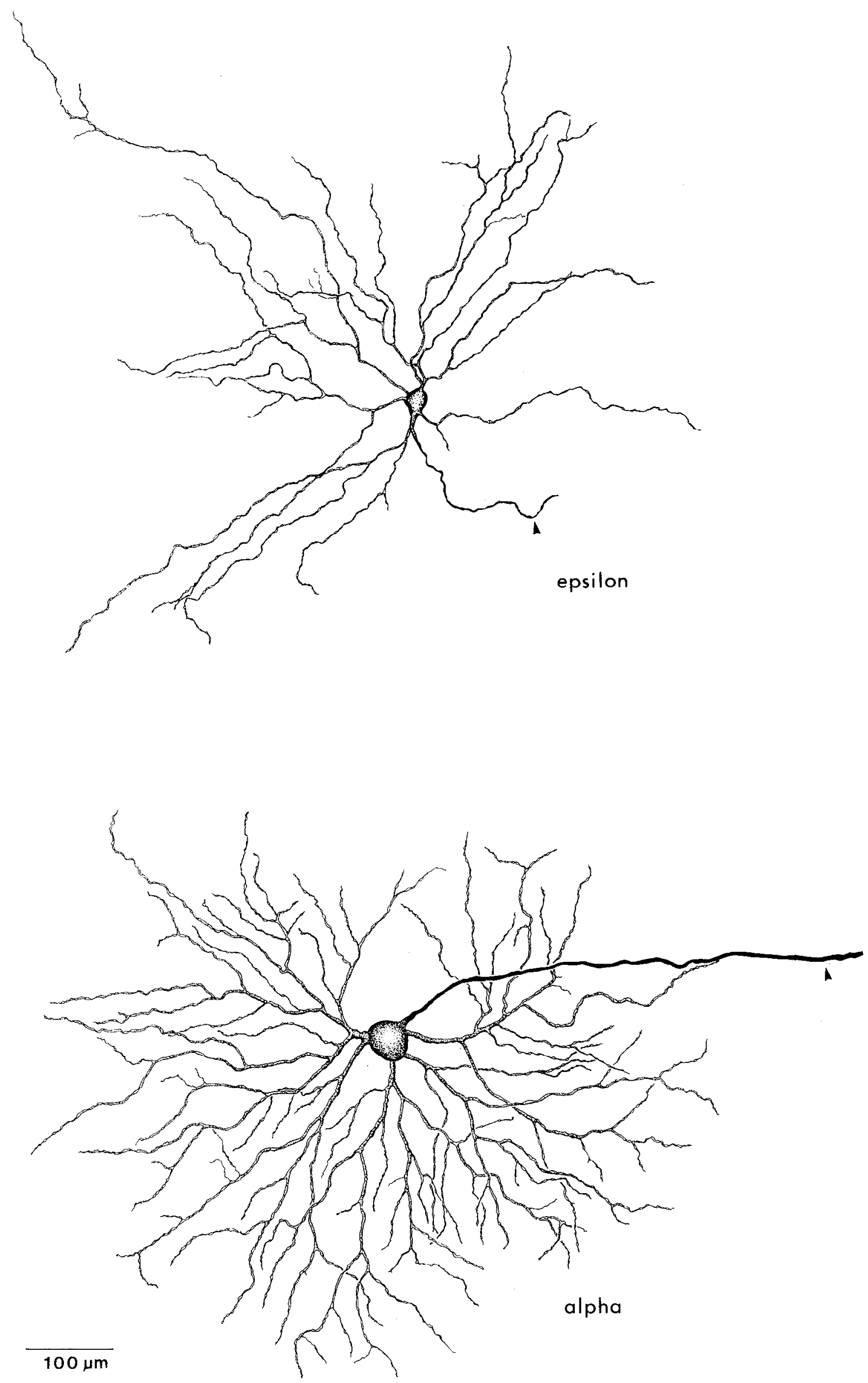

Figure 6. Camera lucida drawings contrasting the morphologies of an $\epsilon$ cell (top) and an $\alpha$ cell (bottom) at matched retinal eccentricities ( 4 mm). Both lay in the temporal retina and were stained by intracellular injection. The $\epsilon$ cell was also labeled by retrogradc transport from the ipsilatcral geniculate wing. Conventions are as for Figure 2. Note that compared to the $\alpha$ cell, the $\epsilon$ cell has a smaller soma, thinner axon, and finer, more sparsely branched dendrites. 


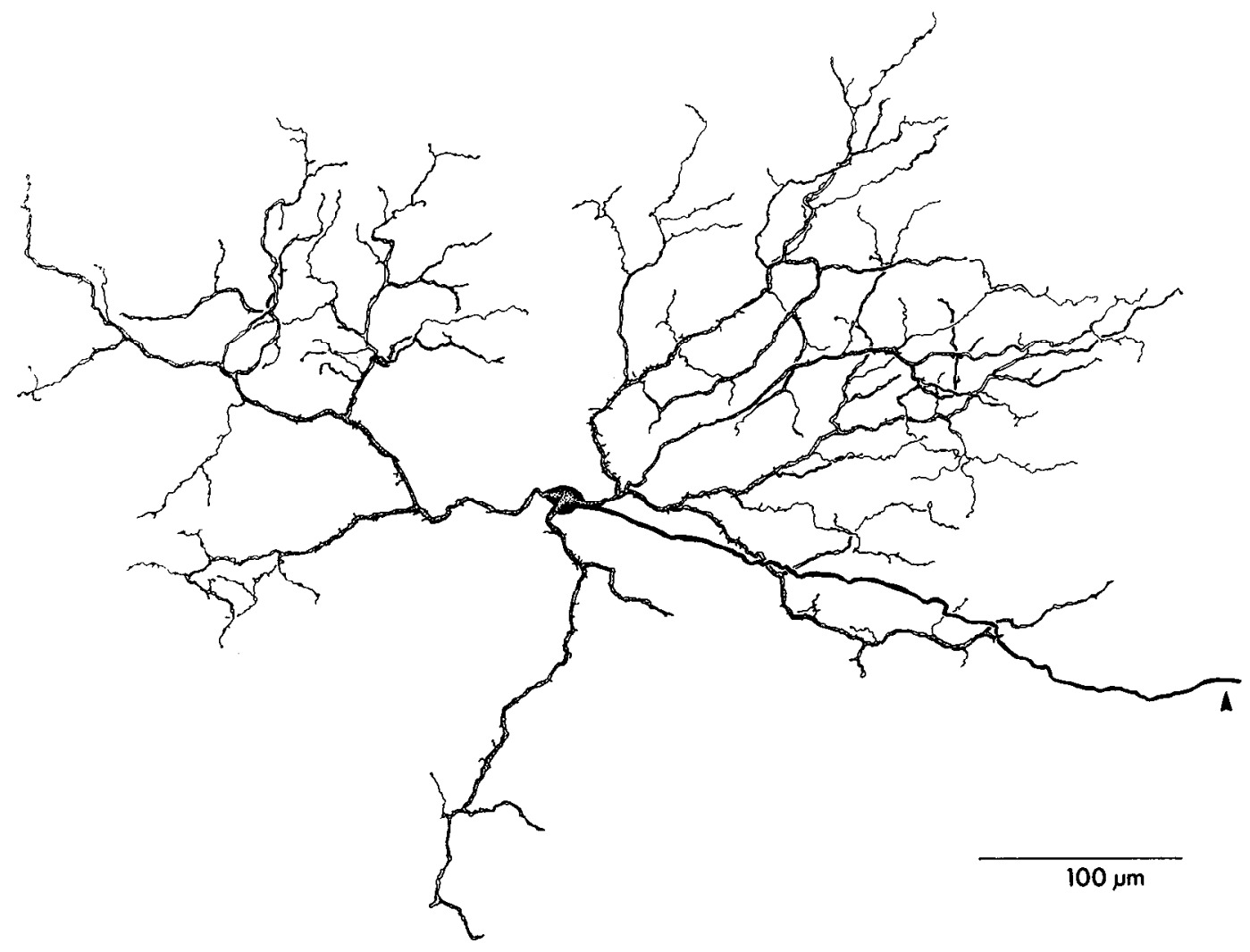

Figure 7. Camera lucida drawing of a highly atypical ganglion cell identified by retrograde transport from the ipsilateral geniculate wing and stained by intracellular injection in vitro. The cell appears distinct from $\epsilon$ cells in that it has a smaller dendritic field and tortuous, spiny dendrites that ramify diffusely in the inner plexiform layer. Eccentricity, $2.6 \mathrm{~mm}$.

which we had tried unsuccessfully to record. Thus, in later experiments we surrounded each intentionally stained cell with a string of dye spots forming an arc, circle, or other distinctive pattern. To make such dye spots, the electrode was positioned just beneath the inner limiting membrane and brief current pulses delivered to stain Müller cells, astrocytes, or other retinal elements with Lucifer yellow.

\section{Results}

\section{Morphology}

Unilateral deposits of fluorescent beads in the geniculate wing labeled medium-sized ganglion cells in both retinas. The distribution of labeling, though not studied systematically, was in keeping with earlier findings (Kawamura et al., 1979; Leventhal et al., 1980). Labeled cells appeared at relatively low density overall, though densities increased near the area centralis. Most labeled cells lay in the superior retina, as expected from the rostral placement of our deposits within the wing (Kawamura et al., 1979). Ipsilateral to the deposit, ganglion-cell labeling was confined to the temporal hemiretina. Contralaterally, most labeled cells lay in the nasal retina but a few could be found nearly $2 \mathrm{~mm}$ (about $8^{\circ}$ ) into the temporal retina.

Our observations on the morphology of these neurons are based on a sample of 151 bead-labeled ganglion cells stained by intracellular injection in six retinas from three cats. With a single exception (see below and Fig. 7), these ganglion cells appeared to belong to a single morphological class, in keeping with earlier suggestions (Leventhal et al., 1980; Rodieck and Watanabe, 1986). Like the " $\epsilon$ cells" that Leventhal et al. (1980) labeled by retrograde transport from the geniculate wing, these neurons (Figs. 1-6) had somas comparable in size to those of $\beta$ cells, large dendritic fields composed of sparsely branching radiate dendrites, and morphologies clearly distinct from the $\alpha, \beta, \gamma$, and $\delta$ cells of Boycott and Wässle (1974). We will therefore adopt the term " $\epsilon$ " to refer to these cells in this report. Our findings pertain specifically to $\epsilon$ cells innervating the geniculate wing. They leave open the possibility that the designation " $\epsilon$ " may prove applicable to other ganglion cells that lack a projection to the wing and that may differ somewhat from the cells described here.

The proximal dendrites of the $\epsilon$ cells in our sample were generally finer than those of $\alpha$ cells (see Fig. 6) but thicker than those of many of the other presumed $W$-cells we have stained with this technique (Pu and Berson 1991a,b; M. Pu and D. M. Berson, unpublished observations). The dendrites tapered gently, but even the terminal branches were fairly stout in most cells (Fig. $1 E$ ). Though the dendrites were typically smooth, many cells had a sparse distribution of spines or short hairs. A few cells were unusually spiny (Figs. $1 F, 2$ ), but these did not appear to constitute a separate cell type since in other respects they resembled the overall population. Periodic swellings were evident on the distal dendrites of most cells, but it was unclear if this reflected a feature of their normal morphology or pathology attributable to the staining technique. $\epsilon$-Cell dendrites typically arose from three to five primary trunks (range, 1-7) and radiated in all directions from a centrally placed soma. However, it was not uncommon to find dendritic branches grouped into several distinct tufts (Figs. $1 B, 3,5$ ), and in a few instances processes were situated almost entirely on one side of the cell body leaving the soma eccentrically placed within the dendritic field (Fig. 4). 


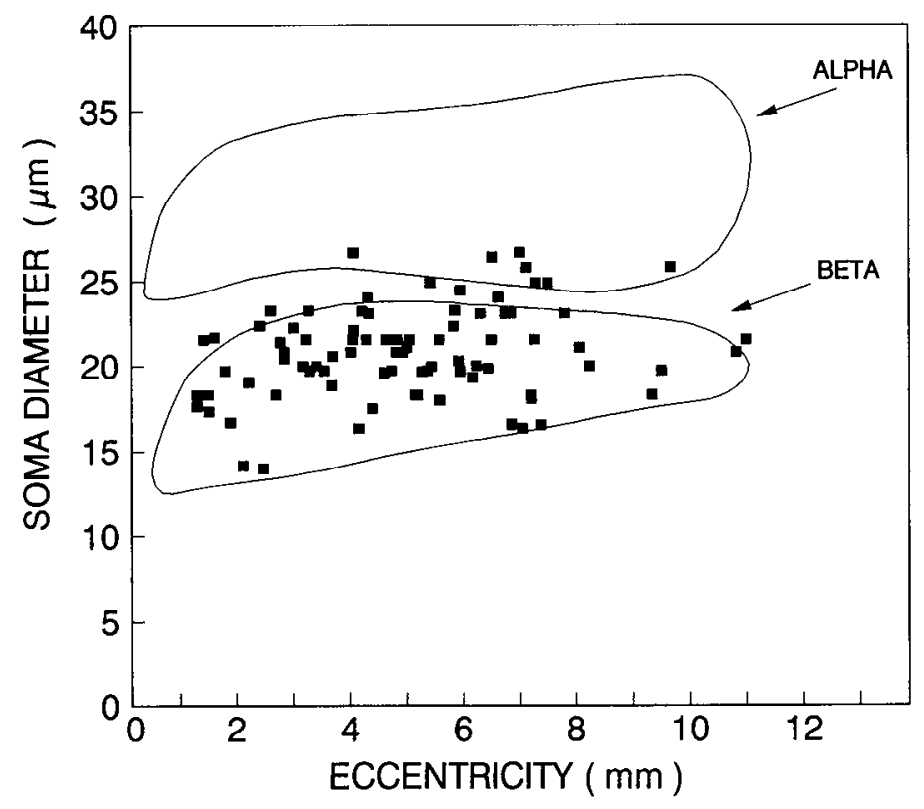

Figure 8. Soma diameters of identified wing-projecting $\epsilon$ cells as a function of eccentricity. Envelopes of $\alpha$ - and $\beta$-cell soma diameters, taken from Boycott and Wässle (1974, their Fig. 9), are shown for comparison. $\epsilon$-Cell somas are generally the same size as those of $\beta$ cells, although they slightly overlap the low end of the $\alpha$ size range. There is little systematic variation with eccentricity.

Dendritic branching was comparatively sparse, with cells having on average a total of only 20 branch points (range, 12-51). Individual dendrites often coursed for hundreds of micrometers without branching and in a few instances primary dendrites terminated without ever doing so. This sparseness was not an artifact of incomplete filling because dendrites were densely stained all the way to their tips where they ended abruptly.

$\epsilon$-Cell somas were of intermediate size within the spectrum of cat ganglion cells (see Figs. $1 C, 8$ ), with an average diameter of $21 \mu \mathrm{m}$ (range, 14-27 $\mu \mathrm{m}$ ). The observed cell-size range overlapped almost completely that reported for $\beta$ cells and slightly extended into the $\alpha$-cell range ( $\Gamma$ ig. 8 ). There was no systematic relationship between soma size and retinal eccentricity.

Axons arose from the soma or, in a few instances (Figs. 3, 6), from a primary dendrite. The axons, which were roughly $1-1.5$ $\mu \mathrm{m}$ in diameter, were the thickest we have observed among the diverse non- $\alpha$, non- $\beta$ cat ganglion cells we have stained with this method ( $\mathrm{Pu}$ and Berson, unpublished observations). They were about as thick as those of $\beta$ cells (Fig. 1D), and much finer than those of $\alpha$ cells (Fig. 6).

Dendritic-field sizes were very large, matching or exceeding those of $\alpha$ cells (Figs. 6, 9). Dendritic-field diameter increased systematically with eccentricity in the central retina, from about $200-400 \mu \mathrm{m}$ near the area centralis to about $500-900 \mu \mathrm{m}$ at 3 $\mathrm{mm}$ eccentricity, but beyond this showed no obvious eccentricity dependence (Fig. 9). The dendritic profiles of $\epsilon$ cells were typically elongated. The major diameter of the dendritic field was on average $40 \%$ longer than the mean diameter and was at least $20 \%$ longer than the mean diameter in $80 \%$ of cells (range, $0-106 \% ; n=123$ ). The elongation of $\epsilon$-cell dendritic fields appeared to occur along axes radiating from the area centralis. To study this tendency quantitatively, we restricted our analysis to 79 cells with at least $20 \%$ elongation, as defined above. We measured for each of these cells the angle between the long axis

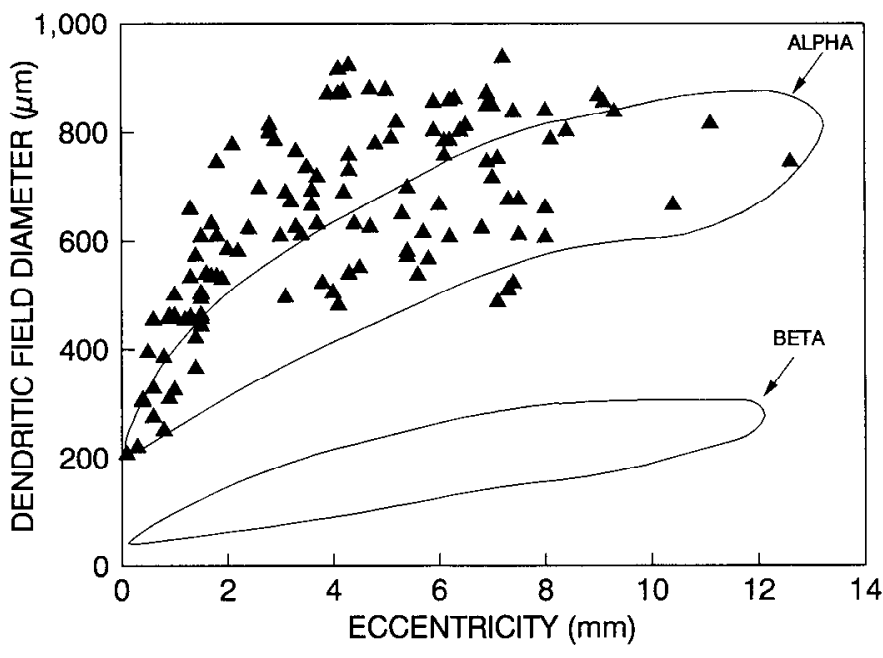

Figure 9. Dendritic-field size as a function of eccentricity for identified wing-projecting $\epsilon$ cells. Dendritic fields get larger with increasing eccentricity within $3 \mathrm{~mm}$ of the area centralis, but exhibit little systematic variation at greater eccentricities. Envelopes of $\alpha$ - and $\beta$-cell dendritic fields, taken from Boycott and Wässle (1974, their Fig. 7), are shown for comparison.

of the dendritic field and the line connecting the cell to the area centralis. The distribution of such "difference angles" (Fig. 10) was markedly skewed toward small values.

The dendrites of $\epsilon$ cells ramified within the inner half of the inner plexiform layer (IPL). This was apparent even in the wholemounted retinas because the dendrites lay in nearly the same focal plane as the ganglion-cell layer. Through-focus analysis of the whole-mounts also suggested that the plane of stratification might be quite limited in depth because overlapping dendrites, whether from a single $\epsilon$ cell or neighboring ones, almost always lie in precisely the same focal plane. The only clear exceptions to this pattern were very proximal dendritic segments, which tended to lie somewhat vitread to the others, and dendrites within a few millimeters of the area centralis, which occasionally

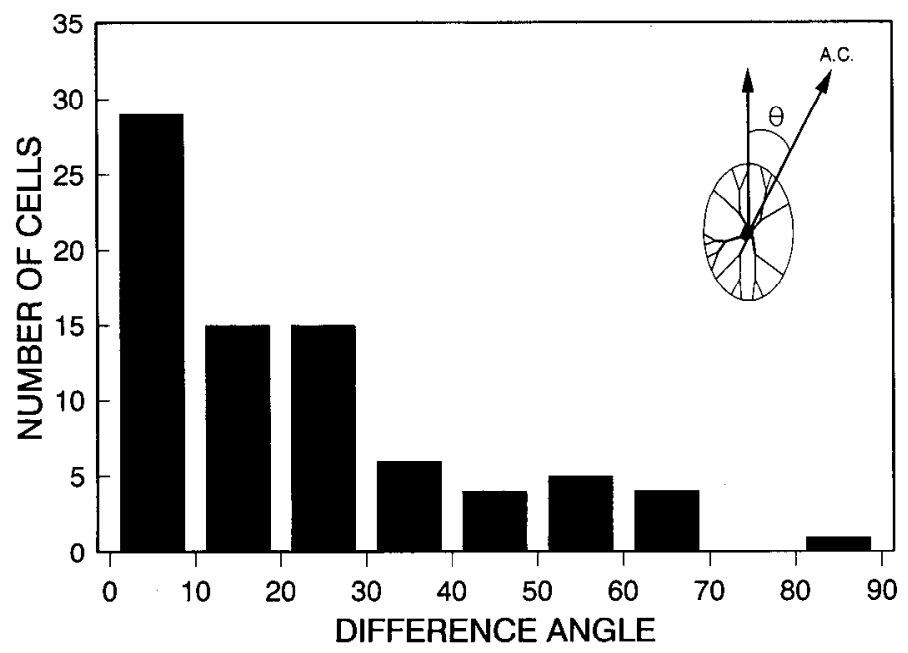

Figure 10. Histogram illustrating the tendency of $\epsilon$-cell dendritic fields to be elongated along axes radiating from the area centralis. For each of 79 cells with marked elongation of their dendritic fields, an angle (" $\theta$ " in inset) was measured between the long axis of the dendritic field (vertical arrow in inset) and the line connecting the soma to the area centralis (A.C.). The histogram illustrates the distribution of such "difference angles," which is clearly skewed toward smaller angles. 

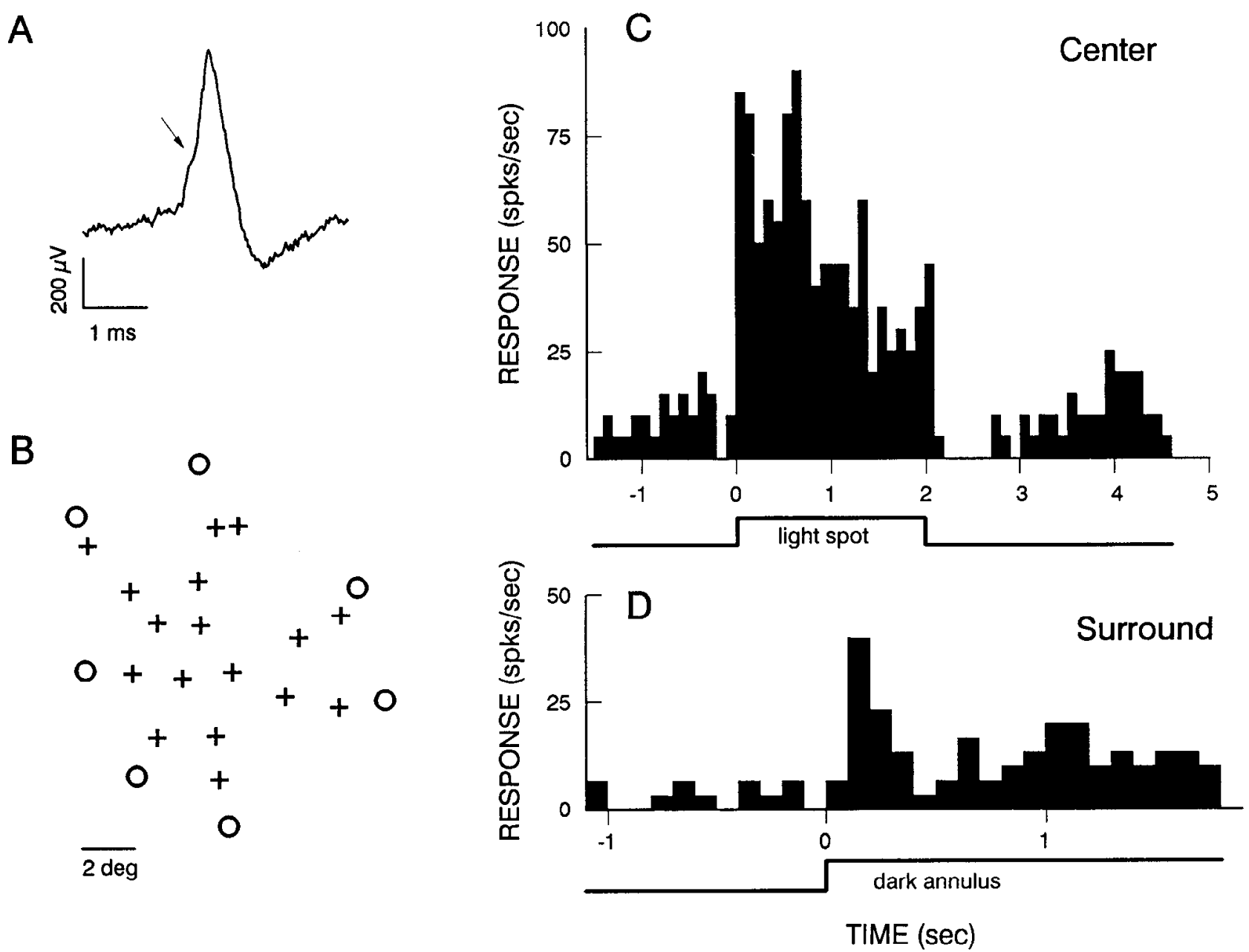

Figure 11. Spike waveform and receptive-field structure of a representative $\epsilon$ cell (cell 12-3) recorded extracellularly in vitro at an eccentricity of $9 \mathrm{~mm}$ in the nasal retina. $A$. Spike waveform. Arrow indicates the inflection on the rising phase of the action potential that is characteristic of somatic recordings of ganglion cells. $B$, Receptive field as plotted with a light spot; + marks locations where onsets of the light spot evoked audible increases in firing; $O$ marks locations where the same stimulus had no effect. Note the large dimensions and ON-center of the receptive field. Spot diameter, 2.1 $1^{\circ}$; spot luminance at screen, $240 \mathrm{~cd} / \mathrm{m}^{2}$; background, $60 \mathrm{~cd} / \mathrm{m}^{2}$. $C$ and $D$, Peristimulus-time histograms illustrating time course of center and surround responses. $C$, Response to a light spot centered on the receptive field, presented for the interval indicated by the stimulus marker below the histogram. Average of two trials. Spot diameter, $3.7^{\circ}$; spot luminance at screen, $95 \mathrm{~cd} / \mathrm{m}^{2} ; \mathrm{background}, 3 \mathrm{~cd} / \mathrm{m}^{2} . D, \mathrm{Response}$ of OFF-surround to onset of a dark annulus. Inner diameter of annulus, $2.1^{\circ}$; outer diameter, about $11^{\circ}$; luminance of annulus at screen, $3 \mathrm{~cd} / \mathrm{m}^{2}$; background, $90 \mathrm{~cd} / \mathrm{m}^{2}$. Average of three trials. Bin width for $C$ and $D, 100 \mathrm{msec}$.

differed slightly from one another in focal plane. However, this through-focus analysis apparently underestimated the breadth of stratification, presumably in part because of the pronounced vertical shrinkage in dehydrated and cleared whole-mounts. Radial sections of a single stained $\epsilon$ cell revealed that its peripheral dendrites ramified anywhere from the middle of the IPL to a level four-fifths of the way toward the ganglion-cell layer, with most processes lying at intermediate depths. $\epsilon$ cells thus appear to ramify within sublayer S4 and the inner half of sublayer S3 of Kolb et al. (1981), a patlern reminiscent of that exhibited by ON- $\beta$ cells (Wässle and Boycott, 1991). To confirm this, we referred to whole-mounted retinas from a companion study in which we had intracellularly stained $\beta$ cells as well as $\epsilon$ cells indistinguishable from those described here $\mathrm{Pu}$ and Berson, 1991a). From through-focus analysis of overlapping dendritic fields, it was evident that $\epsilon$-cell dendrites lay entirely vitread to the dendrites of OFF-type $\beta$ cells, while largely costratifying with those of ON-type $\beta$ cells. Dendrites of ON- $\beta$ cells could sometimes be seen to ramify just sclerad to an $\epsilon$-cell dendrite or, in very rare instances, just vitread to one, but usually no difference in depth could be discerned.

We observed only a single example of a wing-projecting cell that clearly failed to fit the morphological patterns just described and thus presumably belongs to a different morphological class of ganglion cells. This cell (Fig. 7) had a dendritic field smaller than that of any $\epsilon$ cell at comparable eccentricity, and dendrites that were more tortuous, overlapping, and highly branched. Moreover, the dendrites bore a profusion of fine spines and obviously stratified much more diffusely in the IPL than did the $\epsilon$ cells. Its soma was smaller ( $17 \mu \mathrm{m}$ diameter) and its axon slightly finer (about $1 \mu \mathrm{m}$ diameter) than those of neighboring $\epsilon$ cells.

\section{Physiology}

We recorded extracellularly from nine wing-projecting ganglion cells in seven superfused eyecups from five cats. Given the mor- 


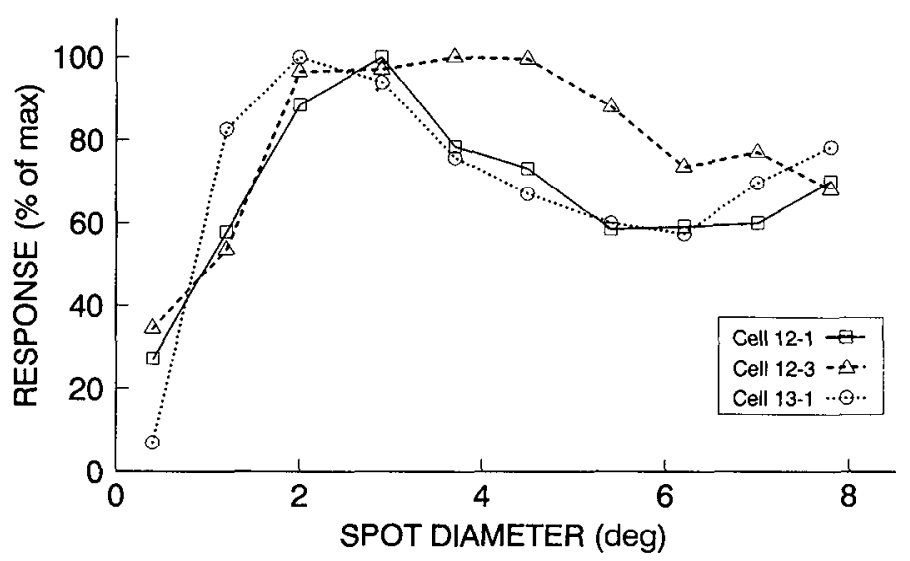

Figure 12. Normalized area-response functions for three wing-projecting $\epsilon$ cells recorded in vitro. Functions were obtained for each cell by summing for each spot size the spikes occurring during the stimulus presentation and expressing this sum as a percentage of the maximum response of that cell. Note that optimal spot sizes ranged from $2^{\circ}$ to $4^{\circ}$ in diameter. For cells 12-1 $(\square)$ and 12-3 $(\triangle)$, each stimulus lasted $2 \mathrm{sec}$ and was presented twice; for cell 13-1 (O), each stimulus lasted 1 sec and was presented five times. Retinal eccentricities: cell 12-1, $4 \mathrm{~mm}$ nasal; cell 12-3, $9 \mathrm{~mm}$ nasal; cell 13-1, $3 \mathrm{~mm}$ temporal.

phological homogeneity among wing-projecting ganglion cells (see above), we are confident that all of these cells belonged to the $\epsilon$ class. This was directly confirmed for four of the recorded cells, which were subsequently stained intracellularly and recovered histologically. Of the remaining five cells, four met all of the following criteria and, together with the four successfully stained cells, constitute a sample of eight cells used for the physiological findings to be reported here: (1) the geniculate wing was the only retinorecipient nucleus involved in the deposit producing their retrograde labeling; (2) retrograde labeling in that retina was restricted to medium-sized cells distributed at low spatial density, as expected for $\epsilon$ cells; (3) the tip of the recording electrode was closely apposed to the labeled cell; (4) the receptive field was spatially in register with the labeled cell; (5) the cell's somadendritic morphology vicwed in vitro (by virtue of retrograde bead labeling and/or Lucifer yellow staining) was consistent with $\epsilon$ morphology; and (6) all bead-laheled cells stained intracellularly in the same retina were $\epsilon$ cells.

To provide comparative data on well-established physiological classes under these experimental conditions, we recorded from eight $\alpha$ and 14 presumed $\beta$ cells in the retinas of six normal adult cats. $\alpha$ cells were unambiguously identifiable in eyecups stained with acridine orange from their large soma size. To obtain $\beta$-cell recordings, wc targeted ganglion cclls of mcdium size. Although not all medium-sized cells are $\beta$ cells, the great majority are (Stone, 1983) and the recorded medium-sized cells all had response properties that were consistent with their being $X$ - (i.e., $\beta$ ) cells. The "null test" (see Results) revealed weak nonlinearities of spatial summation in a few of these cells, but this may have resulted from our use of high-contrast gratings, which can cause X-cells to exhibit such nonlinearities (Hochstein and Shapley, 1976). It is thus very likely that all of the recorded medium-sized cells were $\beta$ cells, and they will be rcferred to as such in this report. We confirmed the identity of four of these as $\beta$ cells by intracellular dye injection.

In keeping with the findings of Jensen (1991) in the rabbit, light responses of cat ganglion cells recovered remarkably quickly in our preparation after the epifluorescence illumination was

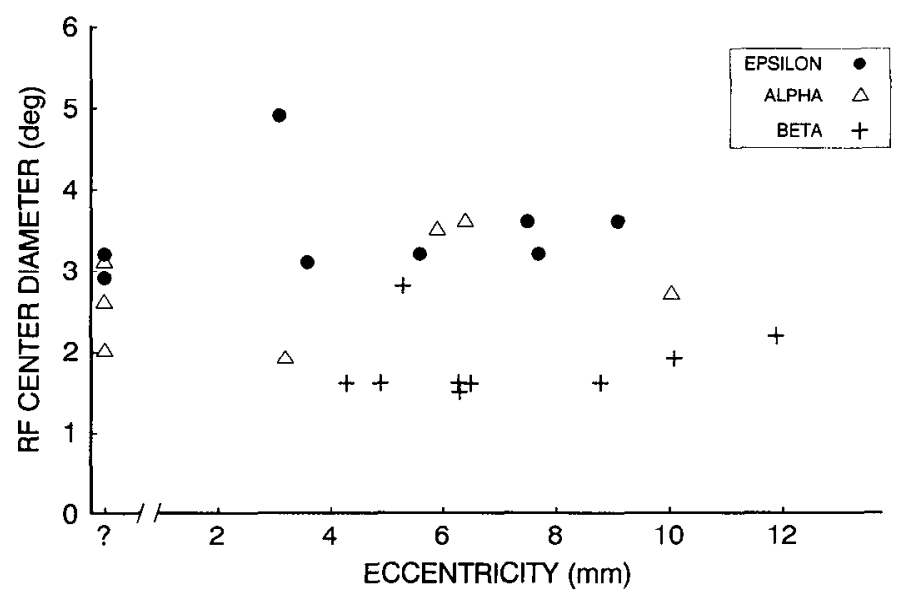

Figure 13. Diameters of the receptive-field centers of cat ganglion cells as function of retinal eccentricity. Receptive-field centers were measured in vitro from plots such as that shown in Figure $11 B$; the plotted values represent the mean of the maximum and minimum diameter for each cell. Points at extreme left represent data from cells for which eccentricity was not determined. $\epsilon$-Cell receptive fields $(\bullet)$ are larger than those of any $\beta$ cells ( +$)$ and match or exceed in size those of $\alpha$ cells $(\Delta)$.

extinguished. Although we have not quantified the time course of recovery, center responses reappeared within a few minutes and responses to sinusoidal gratings of very low contrast (4-8\%) were evident within $20 \mathrm{~min}$. Ganglion-cell responses appeared remarkably unaffected by the relatively cool bath temperature: $\alpha$ and $\beta$ cclls typically had pcak firing ratcs in the range of 50 120 spikes per sec and action potentials of about $1 \mathrm{msec}$ duration (see Fig. $11 A$ ), values comparable to those obtained in vivo (e.g., Cleland et al., 1973; Fukuda and Stone, 1974). The preparations varied in durability, but in most cases good light responses persisted at least $6 \mathrm{hr}$ after eye removal. Retinal detachment appeared to be a major factor leading to deterioration of responsiveness in some preparations.

\section{Receptive-field structure}

All eight recorded $\epsilon$ cells exhibited the same basic physiological features, including large concentric $\mathrm{ON}$-center receptive fields and sustained responses to standing contrast. When plotted with flashed spots of light, the receptive fields appeared as zones within which spot onset elicited a clear and sustained increase in firing rate (Fig. 11). Figure $11 B$ illustrates for a representative $\epsilon$ cell the receptive field plotted in this way. Among our sample of $\epsilon$ cells, receptive-field center diameters ranged from $2.9^{\circ}$ to $4.9^{\circ}(660-1100 \mu \mathrm{m})$. Light spots presented outside this receptive-field center had no effect in most cells, although one cell did give a weak OFF response. Nonetheless, all cells had OFFsurrounds as demonstrated by their responses to light or dark annuli covering the region just outside their receptive-field center (Fig. $11 D$ ). When stimulated with spots of near-optimal size centered on their receptive fields, $\epsilon$ cells showed a marked elevation in firing rate for the duration of the stimulus (Fig. 11C). In many cells, though not all, the sustained response was preceded by a distinct transient component lasting about $200 \mathrm{msec}$. In most cells, the profile of the response did not seem to be dramatically affected by spot size, although in at least some cells the phasic component of the response was enhanced by use of spots larger or smaller than the center. None of the cells showed any indication of direction selectivity. Although wavelength sen- 

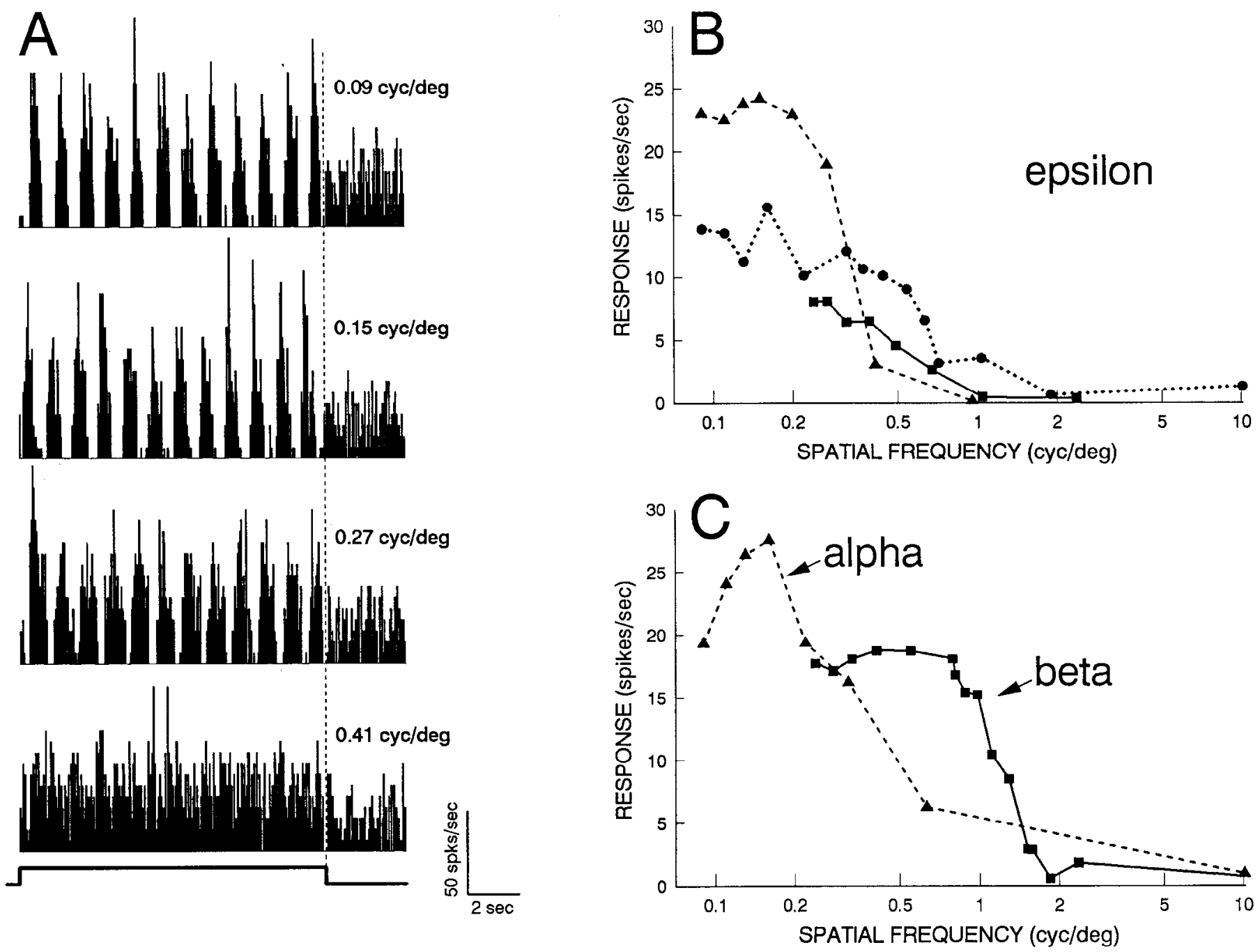

Figure 14. Spatial frequency tuning of wing-projecting $\epsilon$ cells. $A$, Peristimulus-time histograms illustrating the responses of a representative beadlabeled $\epsilon$ cell (cell 12-3) to a sinusoidal contrast grating drifted across the receptive field. Spatial frequency of the grating in degrees of visual angle noted at right. The temporal frequency of the grating was held constant at $1 \mathrm{~Hz}$; contrast was $96 \%$. The grating was visible during the interval marked at the bottom, and was then replaced with a uniform field of matched average luminance $\left(82 \mathrm{~cd} / \mathrm{m}^{2}\right)$. Note the strong modulation at the fundamental stimulus frequency in the top three panels and the clcvated background discharge with littlc modulation for high spatial frequency (bottom panel; $0.41 \mathrm{cycles} /$ degree). $B$, Spatial frequency tuning curves for three $\epsilon$ cells. Curve for cell whose responses are illustrated in $A$ is indicated by $\Delta$; symbols denote same cells as in Figure 12. Response amplitudes shown represent the magnitude of the first harmonic component of the Fourier decomposition. $C$. Spatial frequency tuning curves for representative $\alpha$ and $\beta$ cells recorded in vitro using the same methods as for $B$. Neither $\epsilon$ cells nor $\alpha$ cells respond well to gratings at or above 1 cycle/degree, whereas $\beta$ cells are well driven.

sitivity was not formally tested, these cells plainly did not exhibit color coding of the sort previously described in the cat retina and lateral geniculate nucleus (Pearlman and Daw, 1970; Cleland and Levick, 1974b). Our test stimuli, which were sharply attenuated at short wavelengths (see Materials and Methods), would have been expected to evoke OFF-center responses from the known color-coding cell types, but invariably evoked ONcenter responses in the recorded cells.

Stimulation of the surround of the receptive field suppressed responses evoked from the center. This effect is shown quantitatively for three cells in Figure 12, which plots the cells' responses as a function of the size of a flashed light spot. Each of these cells gave its best response to a limited range of spot size, exhibiting weaker responses both for smaller spots (due to reduced spatial summation within the receptive-field center) and for larger spots (which presumably encroached on the surround mechanism). The peaks of the area-response functions provide a second estimate of the dimensions of the receptive-field center; they ranged from $2.1^{\circ}$ to $4.5^{\circ}$, corresponding well to the estimates based on manual plots (Figs. 11B, 13). The suppression of the center response by larger spots appears relatively modest in Figure 12, but this may underrepresent the strength of surround inhibition in these cells. The outer dimensions of the surround were not determined and may have extended beyond the reach of the largest spots we were able to generate through the computer system $\left(8^{\circ}\right)$. Some $\epsilon$ cells gave little if any response when extremely large light spots were projected directly onto the retina with a hand-held projector.

Figure 13 plots the receptive-field center diameters of recorded $\epsilon$ cells as a function of eccentricity and compares them to those of Y-cells and presumed X-cells recorded under the same conditions. $\epsilon$ cells had receptive-field centers that were comparable in size to the largest of those plotted for the Y-cells and larger than any plotted for X-cells. X-and Y-cells exhibited 
largely nonoverlapping distributions of receptive-field size that were comparable to those observed in vivo (Cleland and Levick, 1974a). There was no obvious relationship between receptivefield size and eccentricity for any class, presumably because of the small sample, especially in the central retina where such effects should be most pronounced.

\section{Spatial frequency turing}

As expected from the large dimensions of their receptive-field centers, $\epsilon$ cells preferred gratings of relatively low spatial frequency. Figure $14 A$ shows in the form of poststimulus-time histograms a typical $\epsilon$ cell's response to drifting, sinusoidally modulated contrast gratings. The cell was clearly modulated at the fundamental stimulus frequency for gratings coarser than about 0.3 cycles/degree, but was unable to follow at higher spatial frequencies. Figure $14 B$ shows summary data for this $\epsilon$ cell and two others. All three were optimally modulated by gratings of $0.1-0.2$ cycles/degree and exhibited little if any audible modulation to gratings of more than 0.8 cycles/degree. Comparable limits for high-frequency resolution were obtained in three other $\epsilon$ cells tested informally with manually controlled square-wave gratings; a fourth appeared to be modulated by such gratings at frequencies as high as 1.1 cycles/degree. There was little evidence of reduced response amplitude at the low end of the spatial-frequency spectrum tested, but the stimulus arrangement did not permit testing at very low spatial frequencies. For comparison, Figure $14 C$ illustrates spatial frequency tuning curves for an $\alpha$ and a $\beta$ cell recorded in vitro at eccentricities comparable to those of the $\epsilon$ cells included in Figure $14 B$. As expected from findings in vivo (Enroth-Cugell and Robson, 1966; Hochstein and Shapley, 1976), the $\alpha$ cell had a spatial frequency tuning curve much like that of the $\epsilon$ cells, whereas the $\beta$ cell preferred higher spatial frequencies (about 0.55 cycles/degree) and had a higher high-frequency cutoff.

Figure 15 summarizes observations on three $\epsilon$ cells exposed to drifting gratings of increasing stimulus contrast. Two of the cells illustrated exhibit essentially linear contrast gain functions, while that of the third is gently saturating. These curves closely resemble those observed in vivo for tonic W-cells by Rowe and Cox (1993) but are shallower than typical for $X$ - and $Y$-cells (e.g., Shapley and Victor, 1978). In three $\epsilon$ cells, we determined the lowest value of contrast at which we could detcet an audible modulation of firing by a drifting sinusoidal grating of optimal spatial frequency; contrast thresholds determined in this way were roughly $15 \%$ in two cells, and about $30 \%$ in a third.

$\epsilon$ cells responded to drifting gratings over a broad range of temporal frequencies. Their firing rates were audibly modulated over the full range of drift rates we tested $(0.05-10 \mathrm{~Hz})$.

\section{Linearity of spatial summation}

To examine the linearity of spatial summation in $\epsilon$ cells, we used a conventional counterphasing grating stimulus. The contrast of a sinusoidal grating was modulated sinusoidally in time and the cell's response evaluated as function of spatial phase. For cells with linear spatial summation, such as X-cells, there is some position of the grating (the "null point") at which the cell exhibits little or no modulation in firing frequency because the space-averaged luminance over the receptive ficld remains essentially constant. By contrast, nonlinear cells such as Y-cells will be modulated at all spatial phases and at grating positions yielding minimal variation in space-averaged luminance this modulation will occur mainly at twice the temporal modulation

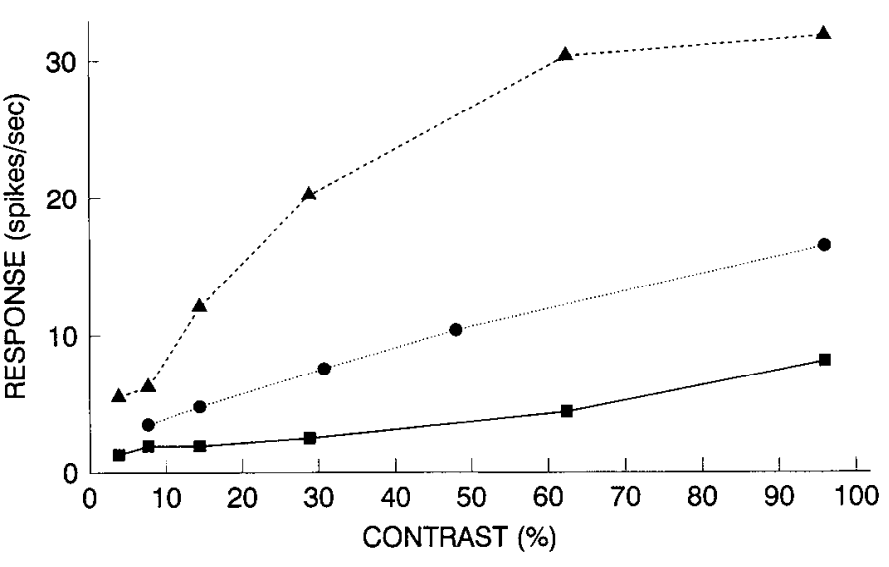

Figure 15. Effect of grating contrast on response magnitude for wingprojecting $\epsilon$ cclls recorded in vitro. Response amplitude represents the magnitude of the first harmonic component of the response to a grating of optimal spatial frequency drifted at a fixed temporal frequency (1 $\mathrm{Hz}$ ). Symbols denote same cells as in Figures 12 and 14.

frequency ("frequency doubling") (see Hochstein and Shapley, 1976).

Figure 16 illustrates the responses of the $\epsilon$ cell studied most fully by this method, and clearly demonstrates nonlinearity of spatial summation in this cell. Figure $16 \mathrm{~A}$ shows peristimulustime histograms of the cell's response to a grating of moderately high spatial frequency $(0.19$ cycles/degree $)$. At a spatial phase of $-168^{\circ}$, the cell was modulated predominantly at the $1 \mathrm{~Hz}$ modulation frequency. The same was true at a spatial phase of $+12^{\circ}$, although the temporal phase of the response was shifted $180^{\circ}$, as expected. Near the expected null point, however, at spatial phases of $-96^{\circ}$ or $+84^{\circ}$, there was plainly modulation at twice the stimulus frequency. Fourier analysis was used to extract the amplitude of the fundamental and second harmonic components of these responses, and the results are summarized in Figure $16 B$. The fundamental component (squares) was large and exhibited a phase dependence that quite faithfully reflected the sinusoidal luminance profile of the stimulus. By contrast, the second harmonic component (triangles) was largely phase independent and considerably smaller than the fundamental, matching its amplitude only at phases where the fundamental component was largely nulled. The mechanisms underlying the first and second harmonic components appeared to have different spatial resolution. When the same cell was tested with a grating of higher spatial frequency $(0.38$ cycles/degree), the amplitude of the fundamental component was markedly reduced, while that of the second harmonic was essentially unchanged (Fig. 16C). In the poststimulus-time histograms, this was reflected in prominent frequency doubling at all spatial phases (not shown). When the same cell was tested using a higher power objective lens, the magnitude of the fundamental component was augmented, presumably in part because the spatial extent of the grating stimulus was reduced and overlapped less of the receptive-field surround (Fig. 16D).

Data for two other $\epsilon$ cells tested with counterphasing gratings are shown in Figure 17, $A$ and $B$. One of these (Fig. 17A) closely resembled the $\epsilon$ cell shown in Figure 16 in exhibiting a large phase-dependent fundamental component and a smaller phaseindependent second harmonic component observable as weak frequency doubling when the fundamental was largely nulled. The other $\epsilon$ cell (Fig. 17B) differed in that the amplitude of its 

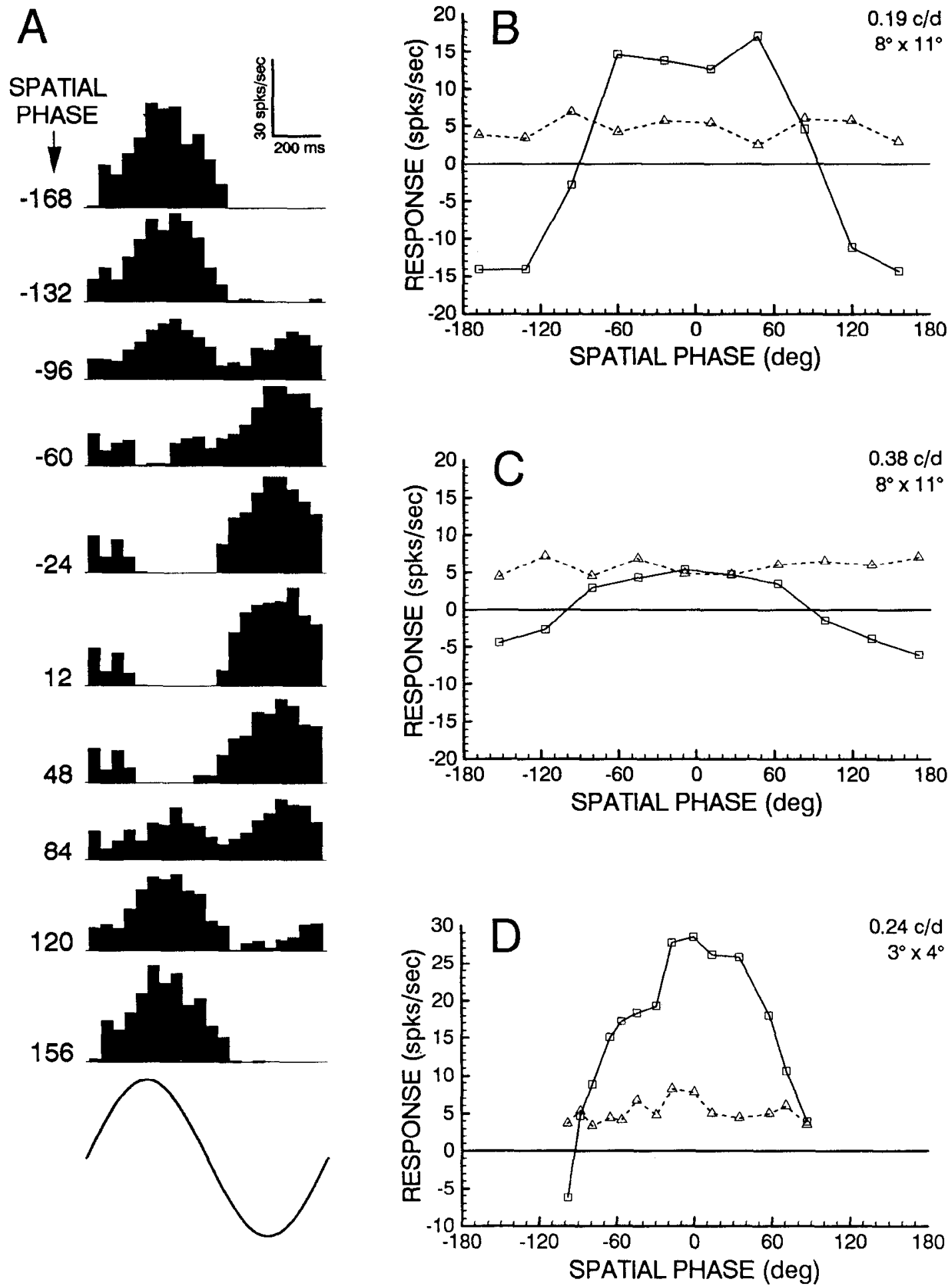

Figure 16. Tests of linearity of spatial summation in a wing-projecting $\epsilon$ cell (cell 12-3) recorded in vitro. A, Peristimulus-time histograms showing the effect of spatial phase on the cell's response to a counterphasing (contrast-reversing) sinusoidal grating. Spatial frequency of grating, 0.19 cycles' degree; extent, $7.9^{\circ} \times 10.6^{\circ}$; peak contrast, $96 \%$. Grating contrast was modulated sinusoidally over time $(1 \mathrm{~Hz})$ as indicated at bottom. Sequential histograms reflect small increments in spatial phase. Strongest responses occur at spatial phases near 0 and $180^{\circ}$ (but are shifted about $180^{\circ}$ in temporal phase, as expected). At spatial phases shifted roughly $90^{\circ}$ from these best positions, there is clear frequency doubling (e.g., phases - $96^{\circ}$ and $+84^{\circ}$ ). B. Quantitative plots of the data shown in $A$. The amplitude of the fundamental component of the response is shown by the solid line, while the amplitude of the second harmonic component (a measure of spatial nonlinearity) is shown by the dashed line. The sign of the fundamental response, positive or negative, reflects its temporal phase relative to the temporal phase of the sinusoidal modulation signal which produced the alternation of the grating. Note that the second harmonic, though smaller than the fundamental, is of substantial size and is essentially phase independent. $C$, Effect of spatial frequency on the relative amplitudes of the first and second harmonic components. Doubling the spatial frequency of the grating to $0.38 \mathrm{cycles} /$ degree (while keeping its extent, contrast, and temporal frequency constant) sharply reduced the amplitude of the fundamental response, but left the second harmonic component virtually unchanged. Under these conditions, frequency doubling was evident at all spatial phases (not shown). $D$, Reducing the area of the grating stimulus by a factor of 6 (by using a higher-power lens) enhanced the fundamental component without affecting the second harmonic. Spatial frequency of the grating, 0.24 cycles/degree; extent, $3.2^{\circ} \times 4.2^{\circ}$; temporal frequency, 1 $\mathrm{Hz}$; peak contrast, $96 \%$ 

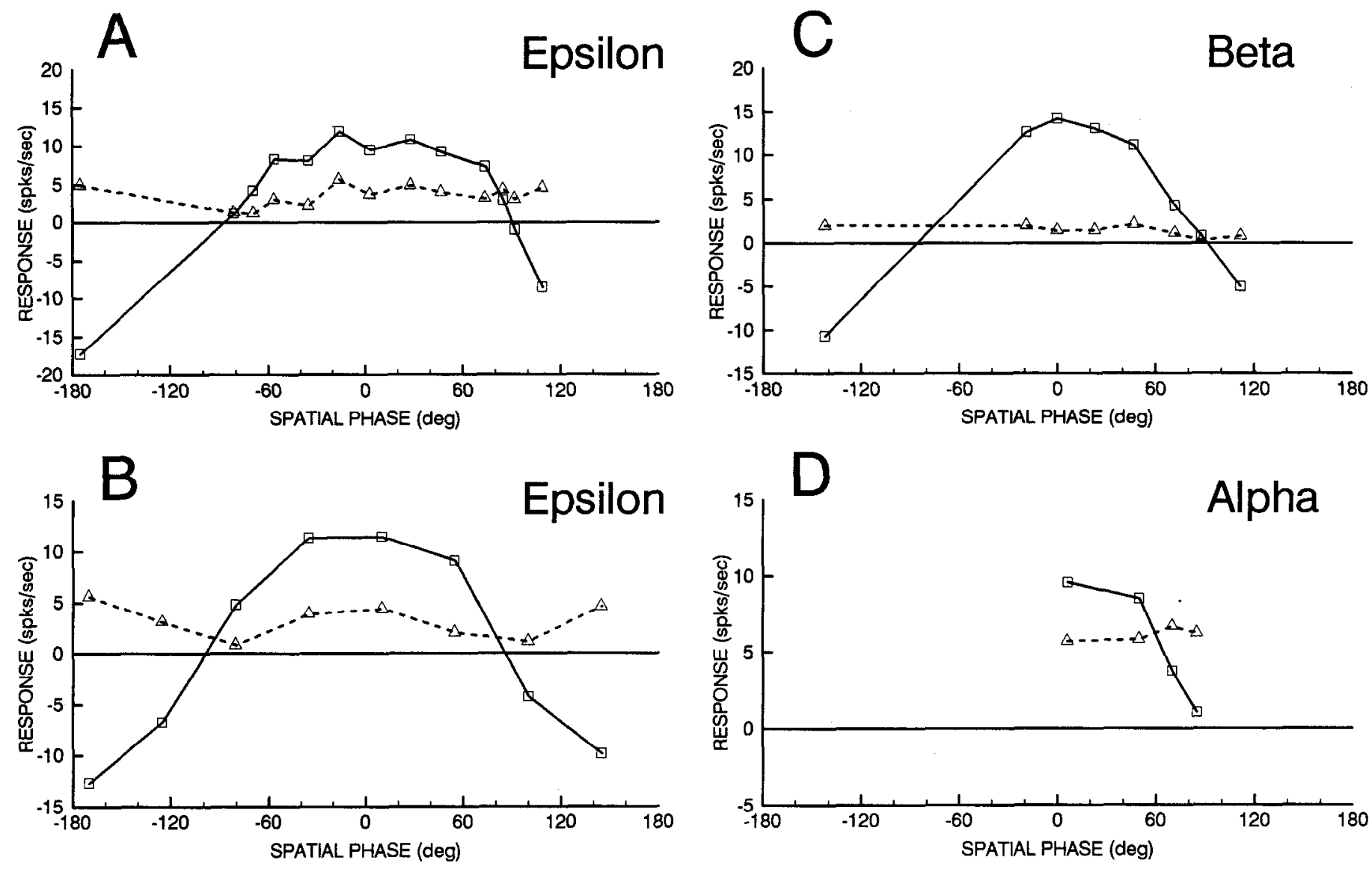

Figure 17. Tests of linearity of spatial summation in two additional wing-projecting $\epsilon$ cells $(A, B)$ and representative $\beta(C)$ and $\alpha$ cells $(D)$ recorded in vitro. Graphic conventions same as for Figure 16 . Note that the second harmonic component is very small for the $\beta$ cell but large and phase independent for the $\alpha$ cell. Stimulus, except for $B, 0.24$ cycles/degree; $3.2^{\circ} \times 4.2^{\circ} ; 1 \mathrm{~Hz} ; 96 \%$ peak contrast. Stimulus for $B, 0.09$ cycles/degree; $7.9^{\circ} \times 10.6^{\circ} ; 1 \mathrm{~Hz} ; 96 \%$ peak contrast.

second harmonic component depended on spatial phase, being roughly proportional to the amplitude of the fundamental. Near the null point, the amplitude of both components was small; no frequency doubling was observed at any spatial phase. Thus, the second harmonic component of this cell's response appears to reflect nonlinearities distinct from those exhibited by the other $\epsilon$ cells tested. These data may underestimate the spatial nonlinearities of $\epsilon$ cells. For example, in Y-cells such nonlinearities are especially evident at relatively high spatial frequencies, whereas the gratings used in our tests were fairly coarse, especially for Figure $17 B$. For comparison, we have examined the responses to counterphased gratings of $\beta$ and $\alpha$ cells recorded in vitro. As expected, $\beta$ cells exhibited very weak second harmonic responses and little or no frequency doubling (Fig. 17C), whereas $\alpha$ cells had a relatively strong second harmonic response and pronounced frequency doubling that was especially obvious at spatial phases yielding a weak fundamental response (Fig. $17 D)$.

The spatial nonlinearities of Y-cells are evident in another aspect of their response to gratings. The cell's mcan firing rate is elevated when a grating is drifted across the receptive field, even when the grating is somewhat finer than the linear center mechanism can resolve (Enroth-Cugell and Robson, 1966). This behavior was evident for two of three $\alpha$ cells tested in vitro; a third $\alpha$ cell failed to show it, but this is probably because in that case the stimulus did not encompass much of the receptive-field surround. As expected, most $\beta$ cells tested (three of five) showed no appreciable elevation of mean firing rate for drifting gratings near the high-frequency cutoff, although a few (two of five) did show a modest (less than twofold) increase. By this measure, $\epsilon$ cells appear to be spatially nonlinear. All three cells tested exhibited a doubling of mean firing rate in response to drifting gratings of high spatial frequency. As shown in the bottom histogram of Figure 14A, this could occur in the absence of any obvious modulation at the fundamental stimulus frequency, just as has been shown for $\mathrm{Y}$-cells.

\section{Responsiveness and regularity of maintained discharge}

$\epsilon$ cells were not obviously more sluggish than $\alpha$ or $\beta$ cells in their responses to visual stimuli. Their peak firing rates were generally comparable to those of $\alpha$ and $\beta$ cells when tested with grating stimuli and could reach levels as high as 150 spikes per sec for brief periods when exposed to bright light flashes. Although the maintained discharges of some $\epsilon$ cells were slightly more regular than those of the $\alpha$ and $\beta$ cells we recorded, this did not appear to be a universal property of $\epsilon$ cells. A conventional measurc of irregularity of maintained discharge is the coefficient of variation, which is the ratio of the standard deviations of the interspike intervals to the mean interval (Robson and Troy, 1987). Coefficients of variation for $\beta$ and $\alpha$ cells ranged from 0.4 to 0.6 , values comparable to those observed in vivo (Robson and Troy, 1987); for $\epsilon$ cells, values ranged from 0.3 to 0.6 . 


\section{Discussion}

The major conclusion of the present study is that ganglion cells innervating the cat's geniculate wing virtually all belong to a single ganglion-cell type, the $\epsilon$ cell. Like the well established $\alpha$ $(\mathrm{Y})$ and $\beta(\mathrm{X})$ cell types, the $\epsilon$ cell possesses a characteristic pattern of morphology, physiology, and central projections and appears to merit a comparable taxonomic status.

The $\epsilon$ cell is likely to be only the first of many such types that will emerge from the heterogeneous group of ganglion cells that are neither $\mathrm{X}(\beta)$ nor $\mathrm{Y}(\alpha)$ and that are sometimes referred to collectively as "W-cells" or " $\gamma$ cells." Among physiologists there is reasonable agreement on the existence of at least eight varieties of receptive fields among these non-X-, non-Y-cells (e.g., Cleland and Levick, 1974a,b; Stone and Fukuda, 1974a; Rodieck, 1979). And while morphologists have reached no consensus upon a classification scheme for the diverse patterns observed within this population (e.g., Boycott and Wässle, 1974; Leventhal et al., 1980; Kolb et al., 1981; Rodieck and Watanabe, 1986; Famiglietti, 1987; Stanford, 1987; Wässle et al., 1987; Dacey, 1989; Pu and Berson, $1991 \mathrm{a}, \mathrm{b}$; Pu et al., 1992), at least two morphological varieties appear about as wcll cstablishcd as the $\epsilon$ cell: the monoamine-accumulating type (Wässle et al., 1987; Dacey, 1989) that is probably equivalent to the $\delta$ cell (Boycott and Wässle, 1974), and the specific type termed " $\gamma$ " by Boycott and Wässle (1974) and "G3" by Kolb et al. (1981). In vitro approaches should accelerate progress toward a comprehensive typology for these cells by facilitating both the identification of morphological types and their correlation with characteristic physiological and connectional signatures.

Leventhal et al. (1980) first raised the possibility that a single morphological class of ganglion cells might provide most or all of the input to the cat's geniculate wing. Even the partial somadendritic filling in their material permitted them to distinguish these cells from any previously described, resembling $\beta$ cells in soma size but having larger and sparser dendritic fields. With the application of intracellular staining techniques (Rodieck and Watanabe, 1986; present study), the differentiation of these neurons from $\alpha$ and $\beta$ cells has become even clearer. For example, the dendritic-field dimensions of $\epsilon$ cells are among the largest ever described for ganglion cells in the cat (Boycott and Wässle, 1974; Kolb et al., 1981) and exhibit no overlap at all with those of neighboring $\beta$ cells. And while the large, radiate dendritic profiles of $\epsilon$ cells bear a superficial resemblance to those of $\alpha$ cells, they are far sparser, exhibiting only about half the total number of branch points that $\alpha$ cells do. In addition, the $\epsilon$ cells have finer proximal dendrites, smaller somas, and thinner axons than $\alpha$ cells. Furthermore, $\epsilon$ cells differ from $\alpha$ cells in failing to exhibit topographic variations in dendritic-field size outside the central retina.

At the same time, the present data underscore the morphological homogeneity of wing-projecting ganglion cells as a group, especially when the effects of eccentricity are taken into account. We have followed the proposal of Leventhal et al. (1980) that they be termed $\epsilon$ cells, extending the Greek lettering scheme begun for cat ganglion cells by Boycott and Wässle (1974). The fact that cells of this class provide essentially the sole retinal input to the geniculate wing allowed us in this study to use retrograde labeling to investigate them in virtual isolation. This may create the mistaken impression that we view a projection to the geniculate wing as an essential characteristic of the $\epsilon$ class. On the contrary, both we and Leventhal et al. (1980) intend this class to be defined by characteristic patterns of morphology, just as is true for the $\alpha$ and $\beta$ classes. Possession of a projection to the wing is neither necessary nor sufficient evidence that a cell belongs to the $\epsilon$ class. For example, at least a few ganglion cells innervating the wing apparently do not fit the morphological profile of $\epsilon$ cclls (Fig. 7), and while it has been suggested that most $\epsilon$ cells project to the wing (Leventhal et al., 1985), the possibility remains that some do not. In this sense, descriptions of $\epsilon$-cell morphology and physiology in this report should be understood to pertain specifically to those $\epsilon$ cells that innervate the wing.

\section{Relationship to previously described morphological types}

Cells very similar to the $\epsilon$ cells described here have appeared in at least three earlier morphological studies of cat ganglion cells. In a Golgi study, Kolb et al. (1981) described a ganglion cell they called $\mathrm{G} 21$, with a fairly large soma (20-25 $\mu \mathrm{m}$ in diameter), a very large, radiate, sparse dendritic arbor, and a large-caliber axon. Like the $\epsilon$ cells described here and by Rodieck and Watanabe (1986), the G21 cell stratified in the inner sublayer of the inner plexiform layer (layers S3 and S4). The G22 cell of Kolb et al. also strongly rescmbles a variant of our $\epsilon$ cells having especially long and sparsely branched terminal dendrites, but the correspondence is inexact because the $\mathrm{G} 22$ cell reportedly ramifies in the OFF sublamina of the inner plexiform layer. In a structure/function study of retinal W-cells, Stanford (1987) stained several ganglion cells that resemble our $\epsilon$ cells, particularly those shown in his Figure $4, A$ and $B$. One of these cells was identified physiologically as an ON-center, tonic W-cell, in agreement with the present physiological findings; the other, also tonic, was not identified as to center type. Though all of Stanford's tonic W-cells shared our $\epsilon$ cell's medium-sized somas and moderately thick axons, no one-to-one correspondence exists between these two groups of cells. Two of Stanford's tonic W-cells differ substantially in dendritic morphology from our $\epsilon$ cells, one of these being ON-center (his Fig. $4 D$ ) and the other OFF-center (his Fig. 4C). Our $\epsilon$ cells are clearly distinct from the specific morphological type termed " $\gamma$ " by Boycott and Wässle (1974) (also termed G3 by Kolb et al., 1981), although they would obviously qualify as " $\gamma$ cells" for those who use this term to refer to all cat ganglion cells that are neither $\alpha$ nor $\beta$ cells. In fact, two of the "medium-soma $\gamma$ cells" illustrated in the Golgi study of Stone and Clarke (1980, their Figs. 1 and $3 D$ ) resemble our $\epsilon$ cells (see also Ramoa et al., 1988, their Fig. $8 E-P 31)$. Probable equivalents of the $\epsilon$ cell have been observed in the retinas of monkeys (Leventhal et al., 1981), ferrets (Vitek et al., 1985), and dogs (Peichl, 1992, his Fig. 4k).

\section{Dendritic-field size, retinal topography, and coverage}

We have shown that the dendritic fields of $\epsilon$ cells increase in size with distance from the area centralis, at least up to $3 \mathrm{~mm}$ eccentricity. This is consistent with the findings of Leventhal et al. (1980) based on retrograde filling and parallels the pattern observed in other well-characterized classes of cat ganglion cells (Boycott and Wässle, 1974; Dacey, 1989). It is likely that this reflects topographic variations in $\epsilon$-cell density. The distribution of $\epsilon$ cells has not been described, but because most of these cells appear to project to the geniculate wing (Leventhal et al., 1985), the distribution of wing-projecting ganglion cells would appear to provide a reasonable indication of the $\epsilon$-cell distribution. On this basis, $\epsilon$ cells would seem to undergo a substantial increase in density from peripheral to central retina (Kawamura et al. 
1979; present study). It can be inferred from the report of Kawamura et al. (1979) that cells labeled by retrograde transport from the wing reached a peak density of about 47 cells $/ \mathrm{mm}^{2}$ within $0.5 \mathrm{~mm}$ of the area centralis. Using a mean dendriticfield area of about $0.05 \mathrm{~mm}^{2}$ for $\epsilon$ cells at this eccentricity (Fig. 9), coverage factor (the product of cell density and dendriticfield area) can be estimated to be about 2.4. In other words, each point in the central retina may be overlapped by the dendritic fields of roughly two or three $\epsilon$ cells. In the periphery, the data of Kawamura et al. (1979) imply an f-cell density of approximately 10 cells $/ \mathrm{mm}^{2}$ and our data indicate a mean dendritic-field diameter of about $0.6 \mathrm{~mm}^{2}$, yielding an estimated coverage of 6 . Comparison of the above density estimates to recent plots of the distribution of all ganglion cells (Wong and Hughes, 1987) suggests that wing-projecting $\epsilon$ cells may constitute at most a few percent of the ganglion-cell population. This is in reasonable agreement with the suggestion of Leventhal et al. (1985), based on retrograde labeling from the optic tract, that about $2 \%$ of cat ganglion cells are $\epsilon$ cells. Nonetheless, the foregoing calculations of $\epsilon$-cell coverage should be viewed as lowerbound estimates because the data of Kawamura et al. (1979) could underrepresent $\epsilon$-cell density if their injections incompletely labeled wing-projecting cells or if some $\epsilon$ cells lack projections to the wing. In any case, the foregoing analysis implics that $\epsilon$-cell coverage exceeds unity everywhere, that is, that the dendritic fields of $\epsilon$ cells completely tile the retina. This is consistent with our observation that, regardless of eccentricity, neighboring $\epsilon$ cells typically have substantially overlapping dendritic fields. Unlike the arrangement among all $\alpha$ cells (Wässle et al., 1981a), this overlap does not reflect the superposition of independent $\mathrm{ON}$ - and OFF-center mosaics, since wing-projecting $\epsilon$ cells appear to be exclusively ON-center. The large dendritic fields of $\epsilon$ cells may reflect, in part, a strategy for achieving complete retinal coverage with a relatively sparse ganglion-cell population.

\section{Implications of dendritic architecture}

The ramification of wing-projecting $\epsilon$ cells exclusively in the $\mathrm{ON}$ sublaycr of the IPL raises the question of whether a paired cell type with OFF sublayer ramifications exists in the cat retina. With the possible exception of the G22 cell of Kolb et al. (1981; see above), none of the cells described in the literature represent clear candidates for a matching OFF-center type. On the other hand, this is hardly conclusive. Few earlier studies of non- $\alpha$, non- $\beta$ ganglion cells have provided data on dendritic stratification. Moreover, recognizing an OFF-type $\epsilon$ cell may not be entirely straightforward if its dendritic profile differs systematically from its ON-type equivalent, as has been reported for $\alpha$ and $\beta$ cells (Wässle et al., 1981b,c). The alternative is that the $\epsilon$ cell constitutes an unpaired, purely $\mathrm{ON}$-center ganglion-cell class. If this is so, it raises the question of why the functional roles played by these cells do not require the balanced, pushpull design of the more familiar paired classes of ganglion cells.

Our data show that $\epsilon$ cells typically have dendritic fields that are clongated along axes radiating from the arca centralis. $\mathrm{Rc}-$ lated findings have been reported for many classes of cat ganglion cells (Leventhal and Schall, 1983) and have been suggested to underlie the weak preferences that most ganglion cells exhibit for gratings of particular orientations (Levick and Thibos, 1982). It remains to be determined to what extent $\epsilon$ cells are orientation selective in this sense.

\section{Physiological properties of $\epsilon$ cells}

Even without the present physiological data, the available morphological evidence would have permitted us to draw certain inferences about the functional properties of $\epsilon$ cells. As pointed out in the original description of these cells (Leventhal et al., 1980), they are distinct from $\alpha$ and $\beta$ cells morphologically and should therefore presumably correspond physiologically to neither X-cells nor Y-cells but rather to some variety of "W-cell." More specifically, their very broad dendritic fields mean that they should have larger receptive fields than those of X-cells, while their medium-caliber axons imply conduction velocities slower than those of $Y$-cells. This extrapolation from anatomical data can be pushed further to narrow the range of candidate $\mathrm{W}$-cell subtypes to which $\epsilon$ cells might correspond. Their relatively thick axons (for non- $\alpha$, non- $\beta$ cells) imply conduction velocities as fast as any among $W$-cells. This, in turn, suggests that they belong to a subgroup of W-cells known as "tonic W-cells" or "W1 cells," (Stone and Fukuda, 1974a; Rowe and Stone, 1977; Rowe and Dreher, 1982; Stanford, 1987). This inference is bolstered by the fact that $\epsilon$ cells have relatively large somas and predominantly ipsilateral projections from the temporal retina, both of which are properties typical of "tonic" W-cells but not of "phasic" ones (Stone and Fukuda, 1974b; Kirk et al., 1976; Rowe and Stone, 1977; Stanford, 1987). The "tonic" or "W 1" group to which $\epsilon$ cells thus presumably belong includes three major varieties of W-cells: tonic ON- and OFFcenter W-cells (also known as sluggish sustained cells), colorcoding cells, and suppressed-by-contrast cells (including "uniformity detectors" and "edge-inhibitory off-center cells") (Cleland and Levick, 1974a,b; Stone and Fukuda, 1974a; Rowe and Stone, 1977). Of these three varieties, only the ON-center tonic $W$-cells have the conventional $O N$-center receptive fields that might be expected for a cell type whose dendritic arbors are confined to the ON sublayer of the IPL. The others seem likely to receive at least some input in the OFF sublayer: colorcoded cells exhibit OFF-center responses to long-wavelength stimuli and suppressed-by-contrast cells either respond equally to light or dark stimuli or exhibit weak OFF-center behavior (Cleland and Levick, 1974b; Stone and Fukuda, 1974a). Thus, the anatomical evidence alone points to $\mathrm{ON}$-center tonic W-cells as the most likely physiological equivalent of $\epsilon$ cells. This prediction is fully borne out by our receptive-field data on these cells. They are $\mathrm{ON}$-center, give sustained light responses, and are presumably $\mathrm{W}$-cells since they are neither $\mathrm{X}$-cells (given their low spatial resolution and spatial nonlinearity) nor Y-cells (given their tonic light responses).

The large soma size of $\epsilon$ cells makes it quite likely that despite their relatively small numbers they have been encountered in earlier extracellular recording studies of cat ganglion cells. Indeed, the $\epsilon$ cells of this report have many physiological traits in common with cells previously included among the ON-center tonic W-cells of Stone and Fukuda (1974a), the ON-center sluggish sustained cells of Cleland and Levick (1974a), and the Q-cells of Enroth-Cugell et al. (1983). However, the correspondence is incomplete. For example, cells in these earlier functional categories typically exhibited background discharges that were unusually regular (Cleland and Levick, 1974a; Stone and Fukuda, 1974a; Robson and Troy, 1987), whereas most $\epsilon$ cells exhibited maintained discharges that were no more regular than those of X- or Y-cells. Likewise, some of the previously recorded cells were "luxotonic," with firing rates that were a monotonic 
function of the intensity of diffuse illumination (Cleland and Levick, 1974a; Stone and Fukuda, 1974a), while at least some $\epsilon$ cells were relatively unresponsive to whole-field illumination. Finally, cells in the earlier studies typically exhibited linearity of spatial summation within their receptive fields (Enroth-Cugell et al., 1983; Stanford, 1987; but see Levick and Thibos, 1980; Rowe and Cox, 1993), whereas some $\epsilon$ cells exhibited unmistakable spatial nonlinearities.

It is not certain how much weight should be assigned to these apparent discrepancies. There are methodological differences between our study and the earlier ones that could account for some of them, and our small data set may underestimate the heterogeneity among $\epsilon$ cells. Nonetheless, there are indications that the population of ON-center, tonic W-cells (or its equivalents) may include morphological forms quite distinct from the $\epsilon$ cell. Structure/function studies have shown ON-tonic W-cells to have diverse morphology, some matching that of our $\epsilon$ cells, others not (Saito, 1983; Stanford, 1987). Likewise, one can identify within the sample of Kolb et al. (1981), as well as within our own unpublished material, a variety of morphological types other than $\epsilon$ cells that are likely to correspond to ON-center tonic W-cells (based on their relatively large somas, inner IPL stratification, and ipsilateral projections from the temporal retina). Finally, there is a set of ON-tonic W-cells that are thought to mediate the pupillary light reflex by virtue of their projections to the olivary nucleus of the pretectum; however, these appear distinct from $\epsilon$ cells not only in their "luxotonic" light responses but also in being located almost exclusively in the inferior retina (Distler and Hoffmann, 1989).

\section{Functional implications}

The present findings imply that the geniculate wing receives its retinal input from a virtually pure population of retinal ganglion cells. This arrangement is unique among all of the subdivisions of the cat's lateral geniculate nuclcus, but has precedents in the primate retinogeniculate pathway. Our results suggest that this retinogeniculate channel carries exclusively $\mathrm{ON}$-channel information. This is in some ways analogous to the segregation of $\mathrm{ON}$-center input within separate leaflets of the A-layers of the lateral geniculate nucleus in certain other carnivores (LeVay and McConnell, 1982; Stryker and Zahs, 1983). An important distinction, however, is that there are corresponding OFF-center leaflets in the A-layers of these animals; there is no known OFFcenter equivalent to the wing, which may well be innervated by an unpaired $\mathrm{ON}$-center class.

The output of the wing is widely distributed among the areas of the cat's visual cortex, reaching areas 17, 18, 19, and the lateral suprasylvian region (Leventhal et al., 1980). What is the nature and functional role of the signals transmitted by this geniculocortical channel? If cells of the wing are like other geniculate neurons in closely following the functional properties of the ganglion cells that innervate them, the present data on $\epsilon$ cells may offer the clearest glimpse yet at the functional specializations of this system. There is little direct evidence on the response properties of postsynaptic cells in the geniculate wing, although a few recordings from this region have been reported (Mason, 1981). The assignment of units to the wing in that study must be considered tentative, because the wing is very thin, is penetrated by diverse vision-related fiber systems, and abuts other visually responsive zones. It is nonetheless of interest that, despite some heterogeneity, all of the units assigned to the wing were $\mathrm{W}$-cells and at least one had the ON-tonic responses ex- pected of a neuron driven by retinal $\epsilon$ cells. It is also noteworthy that these cells were exclusively monocular (Mason, 1981) despite the apparent overlap between the ipsilateral and contralateral eye inputs to the wing (Guillery et al., 1980). This implies that, as for other components of the dorsal lateral geniculate nucleus, binocular interaction may be largely deferred to the cortical level. At this early stage, further speculation on the role of the geniculate wing in visual function is probably premature. Perhaps the best clues to its functions to come from the present work are that they secm to require neither very high spatial precision nor interactions between matched $\mathrm{ON}$ - and OFFchannels.

\section{The in vitro physiological method-validity and utility}

This study employed a novel in vitro technique, so it is natural to ask whether the findings are reliable and representative of the in vivo condition. One concern is that the recordings, being extracellular, might inadvertently have been obtained not from the bead-labeled cells marked by retrograde transport but rather from neighboring axons or somas. There is little doubt that our recordings were obtained from ganglion-cell somas. The electrode tips were visually placed in direct contact with bead-labeled cells and waveforms were typical of somatic recordings (Fukuda and Stone, 1974). Moreover, receptive fields were aligned with the electrode tip, rather than being displaced from it as would be expected for most axonal recordings. Since wingprojecting cells have a stereotyped morphology, one would expect that recordings from such cells would reveal a consistent set of physiological properties, and this was true. What is more, the specific nature of these properties (those of ON-tonic W-cells with large receptive fields) was precisely what would have been predicted from their morphology (see above). There is therefore little doubt that the physiological responses reported here were obtained from the wing-projecting cells we aimed to study.

Another concern is whether the properties recorded in vitro are representative of those that would have been manifest in vivo. The best evidence that they are comes from the close correspondence between the functional attributes of $\mathrm{X}$ - and $\mathrm{Y}$-cells recorded in our eyecup preparation and those recorded in vivo. Thus, while additional work may show our in vitro system to alter ganglion-cell physiology in subtle ways, it seems reasonable to conclude that the broad outlines of $\epsilon$-cell physiology as described here may be extrapolated to the in vivo condition.

The superfused eyecup technique employed in this study provides a practical means of directly correlating the structure, function, and central projections of individual ganglion cells. By providing visual control over electrode position, it also permits targeted recordings from any retinal cell class identifiable by somatic morphology or selective fluorescent marking and should facilitate recordings from cell types with small somas or low spatial densities. As a submerged in vitro preparation, it holds promise for studies of synaptic pharmacology through manipulation of the extracellular medium. The favorable mechanical stability of the preparation supports the prolonged extracellular recordings needed for detailed receptive-field studies and offers a promising new avenue for intracellular analysis of light-evoked responses in the intact cat retina.

\section{References}

Berman N, Jones EG (1977) A retino-pulvinar projection in the cat. Brain Res 134:237-248. 
Bishop PO, Kozak W, Vakkur GJ (1962) Some quantitative aspects of the cat's eye: axis and plane of reference, visual field co-ordinates and optics. J Physiol (Lond)' 163:466-502.

Boycott BB, Wässle H (1974) The morphological types of ganglion cells of the domestic cat's retina. J Physiol (Lond) 240:397-419.

Cleland BG, Levick WR (1974a) Brisk and sluggish concentrically organized ganglion cells in the cat's retina. J Physiol (Lond) 240:421456.

Cleland BG, Levick WR (1974b) Properties of rarely encountered types of ganglion cells in the cat's retina and an overall classification. J Physiol (Lond) 240:457-492.

Cleland BG, Levick WR, Sanderson KJ (1973) Propertics of sustaincd and transient ganglion cells in the cat retina. J Physiol (Lond) 228: 649-680.

Dacey DM (1989) Monoamine-accumulating ganglion cell type of the cat's retina. J Comp Neurol 288:59-80.

Distler C, Hoffmann K-P (1989) The pupillary light reflex in normal and innate microstrabismic cats. II. Retinal and cortical input to the nucleus praetectalis olivaris. Vis Neurosci 3:139-153.

Enroth-Cugell C, Robson JG (1966) The contrast sensitivity of retinal ganglion cells of the cat. J Physiol (Lond) 187:517-522.

Enroth-Cugell C, Robson JG, Schweitzer-Tong DE, Watson AB (1983) Spatio-temporal interactions in cat retinal ganglion cells showing linear spatial summation. J Physiol (Lond) 341:279-307.

Famiglietti EV (1987) Starburst amacrine cells in cat retina are associated with bistratificd, presumably direction selective, ganglion cells. Brain Res 413:404-408.

Famiglietti EV, Kolb H (1976) Structural basis for 'ON' and 'OFF'center responses in retinal ganglion cells. Science 194:193-195.

Farmer SG, Rodieck RW (1982) Ganglion cells of the cat accessory optic system: morphology and retinal topography. J Comp Neurol 205:190-198.

Fukada Y (1971) Receptive field properties of cat optic nerve fibres with special reference to conduction velocity. Vision Res 11:209-226.

Fukuda Y, Stone J (1974) Retinal distribution and central projections of $Y_{-}, X_{-}$, and $W$-cells of the cat's retina. J Neurophysiol 37:749772.

Fukuda Y, Hsiao C-F, Watanabe M, Ito H (1984) Morphological correlates of physiologically identified $\mathrm{Y}_{-}, \mathrm{X}$-, and W-cells in the cat retina. J Neurophysiol 52:999-1013.

Guillery RW, Oberdorfer MD (1977) A study of fine and coarse retinofugal axons terminating in the geniculate $C$ laminae and in the medial interlaminar nucleus of the mink. J Comp Neurol 176:515526.

Guillery RW, Geisert EE Jr, Polley EH, Mason CA (1980) An analysis of the retinal afferents to the cat's medial interlaminar nucleus and to its rostral thalamic extension, the "geniculate wing." J Comp Neurol 194:117-142.

Hochstein S, Shapley RM (1976) Quantitative analysis of retinal ganglion cell classifications. J Physiol (Lond) 262:237-264.

Jensen RJ (1991) Intracellular recording of light responses from visually identified ganglion cells in the rabbit retina. J Neurosci Methods 40:101-112.

Katz L, Iarovici DM (1990) Green fluorescent latex microspheres: a new retrograde tracer. Neuroscience 34:511-520.

Katz LC, Burkhalter A, Dreyer WJ (1984) Fluorescent latex microspheres as a retrograde neuronal marker for in vivo and in vitro studies of visual cortex. Nature 310:498-500.

Kawamura S, Fukushima N, Hattori S (1979) Topographical origin and ganglion cell type of the retino-pulvinar projection in the cat. Brain Res 173:419-429.

Kirk DL, Levick WR, Cleland BG, Wässle H (1976) Crossed and uncrossed representation of the visual field by brisk-sustained and brisk-transient cat retinal ganglion cells. Vision Res 16:225-231.

Kolb H, Nelson R, Mariani A (1981) Amacrine cells, bipolar cells and ganglion cells of the cat retina: a Golgi study. Vision Res 21: $1081-1114$

Kuffler SW (1953) Discharge patterns and functional organisation of mammalian retina. J Neurophysiol 16:37-38.

Lee C, Malpeli JG, Schwark HD, Weyand TG (1984) Cat medial interlaminar nucleus: retinotopy, relation to tapetum and implication for scotopic vision. J Neurophysiol 52:848-869.

LeVay S, McConnell SK (1982) ON and OFF layers in the lateral geniculate nucleus of the mink. Nature 300:350-351.

Leventhal AG, Schall JD (1983) Structural basis of orientation sensitivity of cat retinal ganglion cells. J Comp Neurol 220:465-475.
Leventhal AG, Keens J, Törk I (1980) The afferent ganglion cells and cortical projections of the retinal recipient zone (RRZ) of the cat's "pulvinar complex." J Comp Neurol 194:535-554.

Leventhal $A G$, Rodieck RW, Dreher B (1981) Retinal ganglion cell classes in the Old World monkey: morphology and central projections. Science 213:1139-1142.

Leventhal AG, Rodieck RW, Dreher B (1985) Central projections of cat retinal ganglion cells. J Comp Neurol 237:216-226.

Levick WR, Thibos LN (1980) X/Y analysis of sluggish-concentric retinal ganglion cells of the cat. Exp Brain Res 41:A5-A6.

Levick WR, Thibos LN (1982) Analysis of orientation bias in cat retina. J Physiol (Lond) 329:243-261.

Mason R (1981) Differential responsiveness of cells in the visual zones of the cat's LP-pulvinar complex to visual stimuli. Exp Brain Res 43:25-33.

Nelson R, Famiglietti EV, Kolb H (1978) Intracellular staining reveals different levels of stratification for ON- and OFF-center ganglion cells in cat retina. J Neurophysiol 41:472-483.

Pearlman AL, Daw NW (1970) Opponent color cells in the cat lateral geniculate nucleus. Science 167:84-86.

Peichl L (1992) Morphological types of ganglion cells in the dog and wolf retina. J Comp Neurol 324:590-602.

$\mathrm{Pu}$ M, Berson DM (1991a) Morphology of ganglion cells innervating the medial interlaminar nucleus of the lateral geniculate body. Soc Neurosci Abstr 17:709.

Pu M, Berson DM (1991b) Morphology of retinal W-cells innervating the cat's superior colliculus. Invest Ophthalmol Vis Sci [Suppl] 32: 1133.

Pu M, Berson DM (1992) A method for reliable and permanent intracellular staining of retinal ganglion cells. J Neurosci Methods 41: $45-51$

Pu M, Pan T, Berson DM (1992) Structure and function of ganglion cells projecting to the cat's geniculate wing: an in vitro study. Soc Neurosci Abstr 18:1029.

Ramoa AS, Campbell G, Shatz CJ (1988) Dendritic growth and remodeling of cat retinal ganglion cells during fetal and postnatal development. I Neurosci 8:4239-4261.

Robson JG, Troy JB (1987) Nature of the maintained discharge of Q, $X$, and $Y$ retinal ganglion cells of the cat. J Opt Soc Am 4:2301-2307.

Rodieck RW (1979) Visual pathways. Annu Rev Neurosci 2:193-225.

Rodieck RW, Watanabe M (1986) Morphologic diversity in the ganglion cell projection to different zones within the cat lateral geniculate nucleus. Soc Neurosci Abstr 12:1038.

Rowe MH, Cox JF (1993) Spatial receptive-field structure of cat retinal W cells. Vis Neurosci 10:765-779.

Rowe MH, Dreher B (1982) Retinal W-cell projections to the medial interlaminar nucleus in the cat: implications for ganglion cell classification. J Comp Neurol 204:117-133.

Rowe MH, Stone J (1977) Naming of neurones: classification and naming of cat retinal ganglion cells. Brain Behav Evol 14:185-216.

Saito AH (1983) Morphology of physiologically identified X-, Y-, and W-type retinal ganglion cells of the cat. J Comp Neurol 221:279-288.

Sanderson KJ (1971) The projection of the visual field to the lateral geniculate and medial interlaminar nuclei in the cat. $\mathbf{J}$ Comp Neurol 143:101-118.

Shapley RM, Victor JD (1978) The effect of contrast on the transfer properties of cat retinal ganglion cells. J Physiol (Lond) 285:275-298.

Shatz C (1977) A comparison of visual pathways in Boston and Midwestern Siamese cat. J Comp Neurol 171:205-228.

Stanford LR (1987) W-cells in the cat retina: correlated morphological and physiological evidence for two distinct classes. J Neurophysiol $57: 218-244$.

Stone J (1983) Parallel processing in the visual system: the classification of retinal ganglion cells and its impact on the neurobiology of vision. New York: Plenum.

Stone J, Clarke R (1980) Correlation between soma size and dendritic morphology in cat retinal ganglion cells: evidence of further variation in the gamma-cell class. J Comp Neurol 192:211-217.

Stone J, Fukuda Y (1974a) Properties of cat retinal ganglion cells: a comparison of W-cells with X-and Y-cells. J Neurophysiol 37:722748.

Stone J, Fukuda Y (1974b) The naso-temporal division of the cat's retina re-examined in terms of $\mathrm{Y}-, \mathrm{X}-$, and W-cells. J Comp Neurol 155:377-394.

Stryker MP, Zahs KR (1983) ON and OFF sublaminae in the lateral geniculate nucleus of the ferret. J Neurosci 3:1943-1951. 
Thibos LN, Levick WR (1983) Spatial frequency characteristics of brisk and sluggish ganglion cẹlls of the cat's retina. Exp Brain Res 51: 16-22.

Troy JB, Einstein G, Schuurmans RP, Robson JG, Enroth-Cugell C (1989) Responses to sinusoidal gratings of two types of very nonlinear retinal ganglion cells of cat. Vis Neurosci 3:213-223.

Vitek DJ, Schall JD, Leventhal AG (1985) Morphology, central projections, and dendritic field orientation of retinal ganglion cells in the ferret. J Comp Neurol 241:1-11.

Wässle H, Pcichl L, Boycott BB (1981a) Dendritic territories of cat retinal ganglion cells. Nature 292:344-345.

Wässle H, Peichl L, Boycott BB (1981b) Morphology and topography of on- and off-alpha cells in the cat retina. Proc R Soc Lond [Biol] 212:157-175.

Wässle H, Boycott BB, Illing R-B (1981c) Morphology and mosaic of on- and off-beta cells in the cat retina and some functional considerations. Proc R Soc Lond [Biol] 212:177-195.

Wässle H, Voigt T, Patel B (1987) Morphological and immunocytochemical identification of indoleamine-accumulating neurons in the cat retina. J Neurosci 7:1574-1585.

Wong ROL, Hughes A (1987) The morphology, number, and distribution of a large population of confirmed displaced amacrine cells in the adult cat retina. J Comp Neurol 255:159-177. 